\title{
Beyond Nutrient Deficiency-Opportunities to Improve Nutritional Status and Promote Health Modernizing DRIs and Supplementation Recommendations
}

\author{
Michael I. McBurney 1,2,*(D), Jeffrey B. Blumberg ${ }^{2} \mathbb{D}$, Rebecca B. Costello ${ }^{3}$, Manfred Eggersdorfer ${ }^{4} \mathbb{D}_{\text {, }}$ \\ John W. Erdman, Jr. ${ }^{5}$, William S. Harris ${ }^{6,7}$, Elizabeth J. Johnson ${ }^{2} \mathbb{D}$, Susan Hazels Mitmesser ${ }^{8}$, Robert C. Post ${ }^{9}{ }^{\mathbb{D}}$, \\ Deshanie Rai ${ }^{10}$ and Leon J. Schurgers ${ }^{11}$ (D)
}

check for updates

Citation: McBurney, M.I.; Blumberg, J.B.; Costello, R.B.; Eggersdorfer, M.; Erdman, J.W., Jr.; Harris, W.S.; Johnson, E.J.; Hazels Mitmesser, S.; Post, R.C.; Rai, D.; et al. Beyond Nutrient Deficiency-Opportunities to Improve Nutritional Status and Promote Health Modernizing DRIs and Supplementation

Recommendations. Nutrients 2021, 13, 1844. https://doi.org/10.3390/ nu13061844

Academic Editor: Jose Lara

Received: 8 April 2021

Accepted: 25 May 2021

Published: 28 May 2021

Publisher's Note: MDPI stays neutral with regard to jurisdictional claims in published maps and institutional affiliations.

Copyright: (C) 2021 by the authors Licensee MDPI, Basel, Switzerland. This article is an open access article distributed under the terms and conditions of the Creative Commons Attribution (CC BY) license (https:/ / creativecommons.org/licenses/by/ $4.0 /)$.
1 Department of Human Health and Nutritional Sciences, University of Guelph, Guelph, ON N1H 0B5, Canada

2 Friedman School of Nutrition Science and Policy, Tufts University, Boston, MA 02111, USA; jeffrey.blumberg@tufts.edu (J.B.B.); elizabeth.johnson@tufts.edu (E.J.J.)

3 Center for Magnesium Education and Research, Pahao, HI 96778, USA; rbcostello@earthlink.net

4 Department of Internal Medicine, University Medical Center Groningen, 9713 GZ Groningen, The Netherlands; dr.eggersdorfer@gmail.com

5 Department of Food Science and Human Nutrition, University of Illinois, Urbana-Champaign, IL 61801, USA jwerdman@illinois.edu

6 Department of Internal Medicine, University of South Dakota, Sioux Falls, SD 57105, USA; wsh@faresinst.com

7 The Fatty Acid Research Institute, Sioux Falls, SD 57106, USA

8 Science \& Technology, Pharmavite LLC, West Hills, CA 91304, USA; smitmesser@pharmavite.com

9 FoodTrition Solutions, LLC, Hackettstown, NJ 07840, USA; robert.post@foodtritionsolutions.com

10 Global Regulatory and Scientific Affairs, Omniactive Health Technologies, Morristown, NJ 07960, USA; d.rai@omniactives.com

11 Department of Biochemistry, Cardiovascular Research Institute Maastricht (CARIM), University of Maastricht, 6200 MD Maastricht, The Netherlands; 1.schurgers@maastrichtuniversity.nl

* Correspondence: mcburnem@uoguelph.ca

Abstract: The US Dietary Guidelines for Americans (DGA) provide dietary recommendations to meet nutrient needs, promote health, and prevent disease. Despite 40 years of DGA, the prevalence of under-consumed nutrients continues in the US and globally, although dietary supplement use can help to fill shortfalls. Nutrient recommendations are based on Dietary Reference Intakes (DRIs) to meet the nutrient requirements for nearly all (97 to 98 percent) healthy individuals in a particular life stage and gender group and many need to be updated using current evidence. There is an opportunity to modernize vitamin and mineral intake recommendations based on biomarker or surrogate endpoint levels needed to 'prevent deficiency' with DRIs based on ranges of biomarker or surrogate endpoints levels that support normal cell/organ/tissue function in healthy individuals, and to establish DRIs for bioactive compounds. We recommend vitamin $\mathrm{K}$ and $\mathrm{Mg}$ DRIs be updated and DRIs be established for lutein and eicosapentaenoic and docosahexaenoic acid (EPA + DHA). With increasing interest in personalized (or precision) nutrition, we propose greater research investment in validating biomarkers and metabolic health measures and the development and use of inexpensive diagnostic devices. Data generated from such approaches will help elucidate optimal nutrient status, provide objective evaluations of an individual's nutritional status, and serve to provide personalized nutrition guidance.

Keywords: DRIs; lutein; EPA and DHA; magnesium; vitamin K; dietary guidelines; nutritional status

\section{Introduction}

The second Sustainable Development Goal of the World Health Organization recognizes that nutrition is the foundation of peaceful, secure, and stable societies and the need for better nutrition to improve health and end poverty. While the association of dietary patterns with health is generally accepted, the complexity of the relationship led to the US 
developing the Dietary Guidelines for Americans (DGA) in 1980. Based on the facts that: (1) "about 40 different nutrients to stay healthy, these include vitamins and minerals, as well as amino acids (from proteins), essential fatty acids (from vegetable oils and animal fats), and sources of energy (calories from carbohydrates, proteins, and fats)" and (2) "These nutrients are in the foods you normally eat" [1], the DGA identified seven principles of a healthful diet with the goal of helping reduce nutritional deficiencies and risk of related illnesses. As mandated by Congress in 1990, new DGAs have been issued every 5 years with the 9th edition being released in 2020 [2]. This paper reviews the history of dietary guidance with respect to dietary supplements, nutritional contributions from food and dietary supplement use, and identifies opportunities to update the Dietary Reference Intakes (DRIs) for magnesium and vitamin $\mathrm{K}$ and establish DRIs for lutein and the omega-3 fatty acids, eicosapentaenoic acid (EPA) and docosahexaenoic acid (DHA).

\section{Dietary Guidelines History}

After the first DGA in 1980, a Dietary Guidelines Advisory Committee (DGAC) has convened every 5 years to assess the best available nutrition and health science and produce a scientific report used in the development of the DGA. The DGA are the cornerstone of US nutrition policies and programs, including food assistance and consumer education programs. The purpose of the DGA has evolved over the last 40 years and it now serves as a reference for regional, state, and local organizations, provides information to health professionals and healthcare systems, and functions as a call to action for food product innovators. The role of dietary supplements in national dietary guidance has been given only modest attention in each DGA edition.

The DGA process has changed from guidelines decided by a group of experts to a synthesis of evidence-based reviews, data modeling and analyses to inform conclusions and implications resulting in a comprehensive scientific report of recommendations. In turn, this external Report forms the basis for Federal policy - the DGA — which gives advice for healthy eating patterns applied by the programs of all agencies with food and public health missions. The 1980 DGA recommended that women in their childbearing years may need iron supplements and women who are pregnant or breastfeeding may need more iron, folic acid, vitamin A, and calcium but "rarely need to take vitamin or mineral supplements if you eat a wide variety of foods" [1]. The 1985 DGA cautioned against consuming excessive amounts of any nutrient and state "large dose supplements of any nutrient should be avoided" with key exceptions, e.g., iron supplements of women of childbearing years and acknowledgement for "the need for more of many nutrients" during pregnancy and breastfeeding [3]. Key legislative actions in the 1990s influenced subsequent DGAs, many of which had impacts on nutrient intake needs and recommendations. For example, in 1992, the Department of Health and Human Services (HHS), the Public Health Service, and Centers for Disease Control (CDC) recommended all women of childbearing age consume $400 \mu \mathrm{g}$ of folic acid daily through fortification, supplementation, and diet to prevent neural tube defects [4]. The Nutrition Labeling and Education Act (NLEA) (Public Law 101-535) and recent regulatory amendments $[5,6]$ mandated nutrition labeling requirements on most foods sold at retail [7] including essential nutrients. The US Food and Drug Administration (FDA) proposed a health claim for folic acid and neural tube defects in 1994 [8] and mandated folic acid fortification of cereal grains in 1996 [9] that was subsequently expanded to include corn masa flour [10]. The Dietary Supplement Health and Education Act of 1994 (DSHEA) defined dietary supplements, labeling and manufacturing practices, and established the Office of Dietary Supplements at the National Institutes of Health (NIH) [11]. The 1995 DGA specifically stated "supplements of vitamins, minerals, or fiber may help to meet special nutritional needs" and caveats that "regular use in large amounts may be harmful" and "supplements do not supply all of the nutrients and other substances present in foods" [12]. The 2000 DGA expanded beyond a focus on food variety (to reduce nutritional deficiencies) and moderation (to reduce risk of nutrition-related chronic disease) to include physical activity [13]. The 2005 DGAC adopted a more formalized 
systematic literature search and the focus of DGA policy shifted from the general public to policymakers, health care professionals, nutritionists and nutrition educators [14]. In 2008, the USDA established the Nutrition Evidence Library to conduct food- and nutrition-related systematic reviews and support subsequent DGAC [15]. While the 2010 DGA focused on the status of Americans' health and the prevalence of dietary nutrient inadequacies and deficiencies, the 2015 DGA placed a greater focus on eating patterns. [16]. The 2015 DGA recognized that dietary supplements may be useful in providing one or more nutrients that otherwise may be consumed in less-than-recommended amounts, such as vitamin D [16]. The 2020 DGAC Report reiterated previous DGA reports identifying nutrients of public health concern and related biochemical or chemical indicators, acknowledging that vitamin and mineral supplements can help address vitamin and mineral intake shortfalls (Table 1), and discussing potential risks of overconsumption.

Table 1. Select food components (nutrients) of public health concern with summary by life stage. Adopted from Dietary Guidelines Advisory Committee (2020) [17].

\begin{tabular}{|c|c|c|c|c|c|}
\hline Food Component & Life Stage & $\begin{array}{c}\text { Dietary Intake } \\
\text { Metric }\end{array}$ & $\begin{array}{l}\text { Biochemical or } \\
\text { Clinical Indicator }\end{array}$ & $\begin{array}{c}\text { Associated Health } \\
\text { Condition }\end{array}$ & Last DRI Review \\
\hline Potassium ${ }^{1}$ & $\begin{array}{l}\geq 1 \mathrm{y} \text {, including } \\
\text { pregnant or } \\
\text { lactating women }\end{array}$ & $\%>\mathrm{AI}$ & $\begin{array}{l}24 \text { h urinary } \\
\text { excretion }\end{array}$ & $\begin{array}{c}\text { Hypertension and } \\
\text { cardiovascular } \\
\text { disease }\end{array}$ & 2019 \\
\hline Sodium & $\begin{array}{l}\geq 1 \mathrm{y} \text {, including } \\
\text { pregnant or } \\
\text { lactating women }\end{array}$ & $\%>\operatorname{CDRR}^{2}$ & $\begin{array}{l}24 \text { h urinary } \\
\text { excretion }\end{array}$ & $\begin{array}{c}\text { Hypertension and } \\
\text { cardiovascular } \\
\text { disease }\end{array}$ & 2019 \\
\hline Calcium $^{1}$ & $\begin{array}{l}\geq 1 \mathrm{y} \text {, including } \\
\text { pregnant or } \\
\text { lactating women }\end{array}$ & $\%<$ EAR & $\begin{array}{l}\text { No reliable } \\
\text { biochemical } \\
\text { marker exists }\end{array}$ & $\begin{array}{c}\text { Impaired peak } \\
\text { bone mass accrual; } \\
\text { low bone mass and } \\
\text { osteoporosis }\end{array}$ & 2011 \\
\hline Vitamin $\mathrm{D}^{1}$ & $\begin{array}{l}\geq 1 \mathrm{y} \text {, including } \\
\text { pregnant or } \\
\text { lactating women }\end{array}$ & $\%<$ EAR & $\begin{array}{l}\text { Serum } 25(\mathrm{OH}) \mathrm{D} \\
\text { concentrations }\end{array}$ & $\begin{array}{c}\text { Impaired peak } \\
\text { bone mass accrual; } \\
\text { low bone mass and } \\
\text { osteoporosis }\end{array}$ & 2011 \\
\hline Iron $^{1}$ & $\begin{array}{l}\text { Infants fed human } \\
\text { milk; adolescent, } \\
\text { pre-menopausal, } \\
\text { pregnant women }\end{array}$ & $\%<\mathrm{EAR}$ & $\begin{array}{l}\text { Serum ferritin, } \\
\text { soluble transferrin } \\
\text { receptor, } \\
\text { hemoglobin }\end{array}$ & $\begin{array}{c}\text { Iron deficiency and } \\
\text { iron deficiency } \\
\text { anemia }\end{array}$ & 2001 \\
\hline Iodine & Pregnant women & $\%<$ EAR & $\begin{array}{l}\text { Urinary iodine } \\
\text { concentrations }\end{array}$ & $\begin{array}{c}\text { Impaired } \\
\text { neurocognitive } \\
\text { development }\end{array}$ & 2001 \\
\hline Folic Acid & $\begin{array}{l}\text { Pregnant women, } \\
\text { 1st trimester }\end{array}$ & $\%<$ EAR & $\begin{array}{l}\text { Serum and red } \\
\text { blood cell folate }\end{array}$ & $\begin{array}{l}\text { Neural tube } \\
\text { defects }\end{array}$ & 1998 \\
\hline
\end{tabular}

${ }^{1}$ FDA's designation as a nutrient of "public health significance". ${ }^{2}$ CDRR = Chronic Disease Risk Reduction.

For the first time, the DGAC Report acknowledged that some terms, i.e., "essential nutrients", "nutrients of concern" (and subgroups "under-consumed", "over-consumed", and "shortfall"), and "nutrients of public health concern" are consistently defined and used in the literature, and that scientific assessment and policy development are hampered by a lack of consistent use of terms for biochemical indicators such as "deficiency", "insufficiency/inadequacy", "sufficient/adequate" and "optimal nutrition" [17]. As consumer interest in personalized nutrition grows, the NIH has issued a notice of Intent to Publish a funding opportunity for "Nutrition for Precision Health" for research to provide more targeted and dynamic nutritional recommendations for individuals and their health care providers in January 2021 [18]. The 2020 DGA acknowledges that personal preferences, cultural traditions and budgetary considerations affect dietary choices and encourages people to choose healthy dietary patterns, recognizing that in some cases, fortified foods 
and dietary supplements are useful when it is not possible to meet needs for one or more nutrients, e.g., during pregnancy [2].

\section{Understanding Population Derivation and Use of RDAs}

With the exception of the discovery of mineral element essentiality in the 19th century [19], the nutritional essentiality of amino acids [20], fatty acids [21] and vitamins [22] was established early in the 20th century. Recommended Dietary Allowances (RDAs) were introduced to serve as a guide for planning adequate nutrition for the military and civilians [23] and evolved into Dietary Reference Intakes (DRIs) that consisted of Estimated Average Requirements (EAR), RDAs, Adequate Intake (AIs) and Tolerable Upper Intake Levels (UL) in 1993 [24]. RDAs are target intake levels of essential nutrients judged to be adequate to meet the needs of practically all (97-98\%) healthy persons [25]. RDAs are based on: (1) studies of people eating diets that were low or deficient in the nutrient, (2) nutrient balance studies, (3) biochemical measures of tissue saturation or function, (4) nutrient intake data, (5) epidemiological observations of nutrient intake, and (6) extrapolation from animal experiments [25]. The EAR is the nutrient intake value estimated to meet the requirement defined by a specified indicator of adequacy in $50 \%$ of the individuals in a life stage and sex group [26-30]. An AI, a value based on observed or experimentally determined approximations of nutrient intake of healthy people, is set instead of an RDA when the scientific evidence is insufficient to calculate an EAR. The UL is the highest level of nutrient intake that is likely to pose no risk of adverse effects for most people. The DRIs do not include dietary bioactive compounds, i.e., natural constituents of food that provide health benefits [31], typically because there has been a lack of nutrient databases and dietary intake data.

\section{Nutrient Gaps in the US and the Role of Dietary Supplements}

For the past 40 years, data consistently show that Americans have not been and are still not consuming recommended amounts of whole grains, vegetables, fruits, and dairy foods, and to a lesser extent, protein food groups [17]. This translates to significant proportions of the US population who are consuming less than the EAR or AI for essential nutrients even though $\sim 50 \%$ of US adults take at least one dietary supplement [32-35].

Products containing vitamins and minerals are the most often consumed dietary supplements $[35,36]$. Thus, dietary supplement use is associated with higher vitamin and mineral intake and a lower proportion of the population consuming $<$ EAR for key micronutrients [33,37-39]. The decrease in $\%$ of population $<$ EAR observed with vitamin and mineral supplement use depends on the nutrient, age, and sex groups, and other characteristics, e.g., food security, pregnancy. For example, $91.5 \%$ of men and $98.4 \%$ of women $\geq 19$ years do not meet requirements for vitamin $\mathrm{D}$ from food and beverages and this shortfall drops to $66.4 \%$ of men and $59.1 \%$ of women when intake from supplements is included [40]. While dietary supplements may help meet dietary recommendations, use of multiple nutrient-containing supplements, especially high-dose forms, may increase the risk of exceeding the UL as $\sim 70 \%$ and $30 \%$ of adults $\geq 60$ years report using $\geq 1$ and $\geq 4$ dietary supplement in the past 30 days, respectively [35]. However, data from NHANES $2009-2012$ find $\leq 2.6 \%$ of adults $\geq 71$ years exceed the UL when food and supplement intake is combined, except for zinc where $5.2 \%$ exceed the UL [39]. It is also important to note that global data show micronutrient intakes do not meet dietary recommendations in many countries [41].

\section{Defining Optimal Nutrition and Lessons from Nutrients Considered Essential}

Inadequate intake of essential nutrients is known to cause deficiency diseases and increase the risk of NCD [42,43]. Albert Szent-Gyorgi, recipient of the 1937 Nobel Prize in Physiology and credited with first isolating vitamin C, is quoted as saying "The medical profession itself took a very narrow and wrong view. Lack of ascorbic acid caused scurvy, so if there is no scurvy there was not a lack of ascorbic acid. Nothing could be clearer than 
this. The only trouble was that scurvy is not a first symptom of a lack but a final collapse, a premortal syndrome and there is a wide gap between scurvy and full health" [44]. In other words, setting nutrient intakes using biomarker cutoffs to prevent deficiency disease is not optimizing nutritional status for health or quality of life. When nutrient biomarkers or surrogate endpoints are measured, the health gap between 'deficient' and 'sufficient/adequate' becomes apparent. Nutritional biomarkers or surrogate endpoints should reflect long term nutritional status with limited within-day or day-to-day variability. In some cases, biomarkers or surrogate endpoints may need to be adjusted for other indicators, e.g., according to WHO guidelines on the use of ferritin concentrations to assess iron status in individuals with inflammation or infection [45]. Keeping in mind that RDAs are the average dietary intake level that is sufficient to meet the nutrient requirement of $97-98 \%$ of healthy individuals and AIs are set based on experimentally derived intake levels or approximations of observed mean nutrient intakes of healthy people, we recommend that RDAs and AIs for micronutrients and bioactive compounds be established (EPA + DHA, lutein) or updated (vitamin K, magnesium) based on biomarker or surrogate endpoint concentration ranges that optimize healthy cell/organ/tissue function, as has been carried out for vitamin $\mathrm{D}$.

In 1997, an AI was set for vitamin D with a goal of maintaining (in individuals with limited or uncertain sun exposure and stores) serum 25(OH)D concentrations above a defined amount to prevent vitamin D deficiency rickets or osteomalacia [46]. Recognizing that serum $25(\mathrm{OH}) \mathrm{D}$ served as a reflection of total vitamin D exposure (dietary and skin synthesis by sunlight), new RDAs were established in 2011 for healthy individuals to maintain a serum $25(\mathrm{OH}) \mathrm{D}$ concentration $\sim 50 \mathrm{nmol} / \mathrm{L}(20 \mathrm{ng} / \mathrm{mL})$, which is needed to support skeletal health $[26,47]$. The release of a standard reference material for vitamin $D$ in 2009 [48] had been a significant development for vitamin D research since its availability increased the reliability of $25(\mathrm{OH}) \mathrm{D}$ data. Thus, the $2011 \mathrm{RDA}$ for vitamin $\mathrm{D}$ was based on a shift in target serum $25(\mathrm{OH}) \mathrm{D}$ cutoffs associated with deficiency in a serum $25(\mathrm{OH}) \mathrm{D}$ to a level sufficient to maintain skeletal health in healthy people (Figure 1) [26,49]. The 2011 DRI Report states serum 25(OH)D levels $<30 \mathrm{nmol} / \mathrm{L}$ ( $12 \mathrm{ng} / \mathrm{mL}$ ) increase risk of skeletal deficiency diseases and some persons may be at risk of inadequacy between 30 and $50 \mathrm{nmol} / \mathrm{L}$ (12 and $20 \mathrm{ng} / \mathrm{mL}$ ). Practically everyone would be sufficient at $50 \mathrm{nmol} / \mathrm{L}$ $(20 \mathrm{ng} / \mathrm{mL})$ whereas levels $>75 \mathrm{nmol} / \mathrm{L}(30 \mathrm{ng} / \mathrm{mL})$ were not consistently associated with increased benefit and there may be some concern at $25(\mathrm{OH}) \mathrm{D}$ concentrations $>125 \mathrm{nmol} / \mathrm{L}$ (50 ng/mL). Using NHANES (2001-2006) data from adolescents (12-19 y), bone mineral density was positively associated with serum $25(\mathrm{OH}) \mathrm{D}$ with an inflection point at $\sim 60 \mathrm{nmol} / \mathrm{L}$ (24 ng/mL) [50]. A systematic literature search from May 15 to December 202020 found low serum 25(OH)D level was significantly associated with a higher risk of COVID-19 infection [51].

Vitamin $C$ is required to prevent scurvy; deficiency is defined as plasma ascorbic acid $<11 \mu \mathrm{mol} / \mathrm{L}$, while plasma saturation occurs $\sim 70 \mu \mathrm{mol} / \mathrm{L}$ [28]. Scurvy can be prevented with as little as $10 \mathrm{mg}$ vitamin $C$ per day [52]. Vitamin C intake recommendations globally vary almost 3-fold based on the choice of biomarker, e.g., plasma level, tissue saturation, neutrophil ascorbate concentration, and/or a combination, used by different expert committees [53]. Vitamin C, an enzyme cofactor for collagen and carnitine biosynthesis, is essential for skeletal muscle structure and function [54]. When healthy adult men with vitamin C levels $<50 \mu \mathrm{mol} / \mathrm{L}$ are supplemented, plasma levels increase to $>70 \mu \mathrm{mol} / \mathrm{L}$ within a week and after 4 weeks, there is a significant increase in neutrophil vitamin C content and $20 \%$ increase in neutrophil chemotaxis post-intervention. Mortality increases with low vitamin C status in US men, but not women, with a $62 \%$ increased risk of dying from cancer with serum ascorbate levels $<28 \mu \mathrm{mol} / \mathrm{L}$ vs. $\geq 74 \mu \mathrm{mol} / \mathrm{L}$ [55]. A meta-analysis of 15 prospective cohorts ( $n=320,548$ participants) and 3 prospective within interventional studies ( $n=17,974$ cases) finds a U-shaped association between circulating ascorbate concentrations and risk of CVD mortality (Figure 2) [56]. Even though vitamin C deficiency $(<11 \mu \mathrm{mol} / \mathrm{L})$ appears globally ( $8 \%$ in US, $12 \%$ in Singapore, $14 \%$ in Canada, $14 \%$ in 
France, 20\% in Scotland) [57], there is still no consensus on definitions for "inadequate" or "adequate/sufficient" status [57].
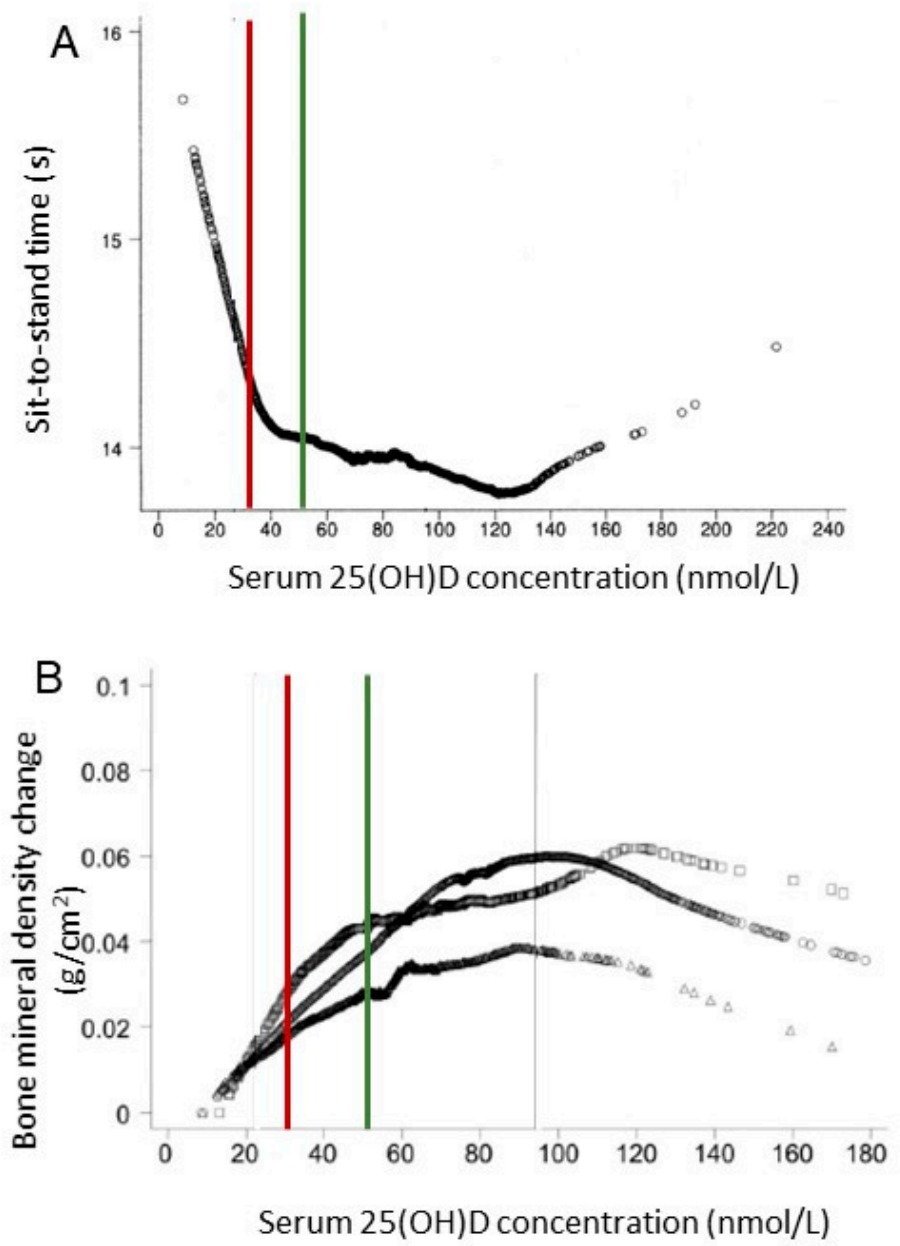
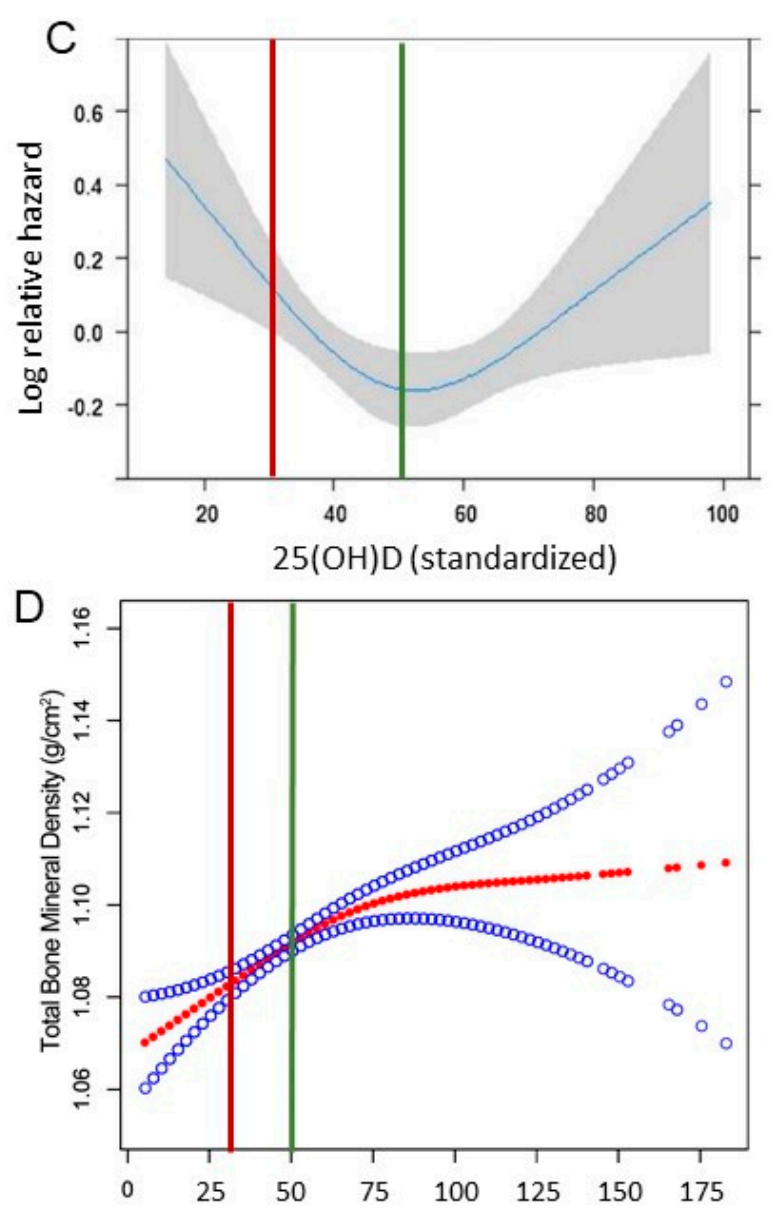

Serum 25(OH)D concentration ( $\mathrm{nmol} / \mathrm{L}$ )

Figure 1. Serum 25(OH)D concentration relationship with different structural or functional outcomes. (A). Serum 25(OH)D concentrations relationship with sit-to-stand time in adults with mean age 71 years (49\% female) controlled for sex, age (5-year categories), race/ethnicity, BMI, poverty income ratio, daily calcium intake, number of medical comorbidities, use of a walking device, self-reported arthritis, activity level, and month of vitamin D measurement. From [47]. (B). Serum $25(\mathrm{OH}) \mathrm{D}$ concentration relationship with bone mineral density in adults $\geq 50$ years after adjustment for sex, age, BMI, smoking, calcium intake, estrogen use, month of vitamin D measurement, and poverty income ratio. From [47]. (C). Spline curve describing the association between $25(\mathrm{OH}) \mathrm{D}$ concentration and recurrent fallers in the total population. From [49]. (D). The association between serum 25(OH)D level and total bone mineral density from NHANES 2001-2006 among 5990 adolescents (12-19 years). Solid red line represents the smooth curve fit between variables. Blue band represents the $95 \%$ confidence interval from the fit. Adjusted for age, gender, race/ethnicity, income to poverty ratio, education, physical activity, body mass index, calcium use. From [50]. Vertical line indicates vitamin D deficiency cutoff, i.e., serum $25(\mathrm{OH}) \mathrm{D}<30 \mathrm{nmol} / \mathrm{L}$ (red), used in setting DRI [46] and insufficiency cutoff, i.e., serum $25(\mathrm{OH}) \mathrm{D}<50 \mathrm{nmol} / \mathrm{L}$ (green), used in updating DRI [26].

Vitamins, minerals, and some amino acids and long-chain fatty acids are defined as essential nutrients because of known deficiency diseases. However, systemic availability of nutrients above cutoffs used to define deficiency may be insufficient to maintain normal cellular structure and/or function of organ systems. 


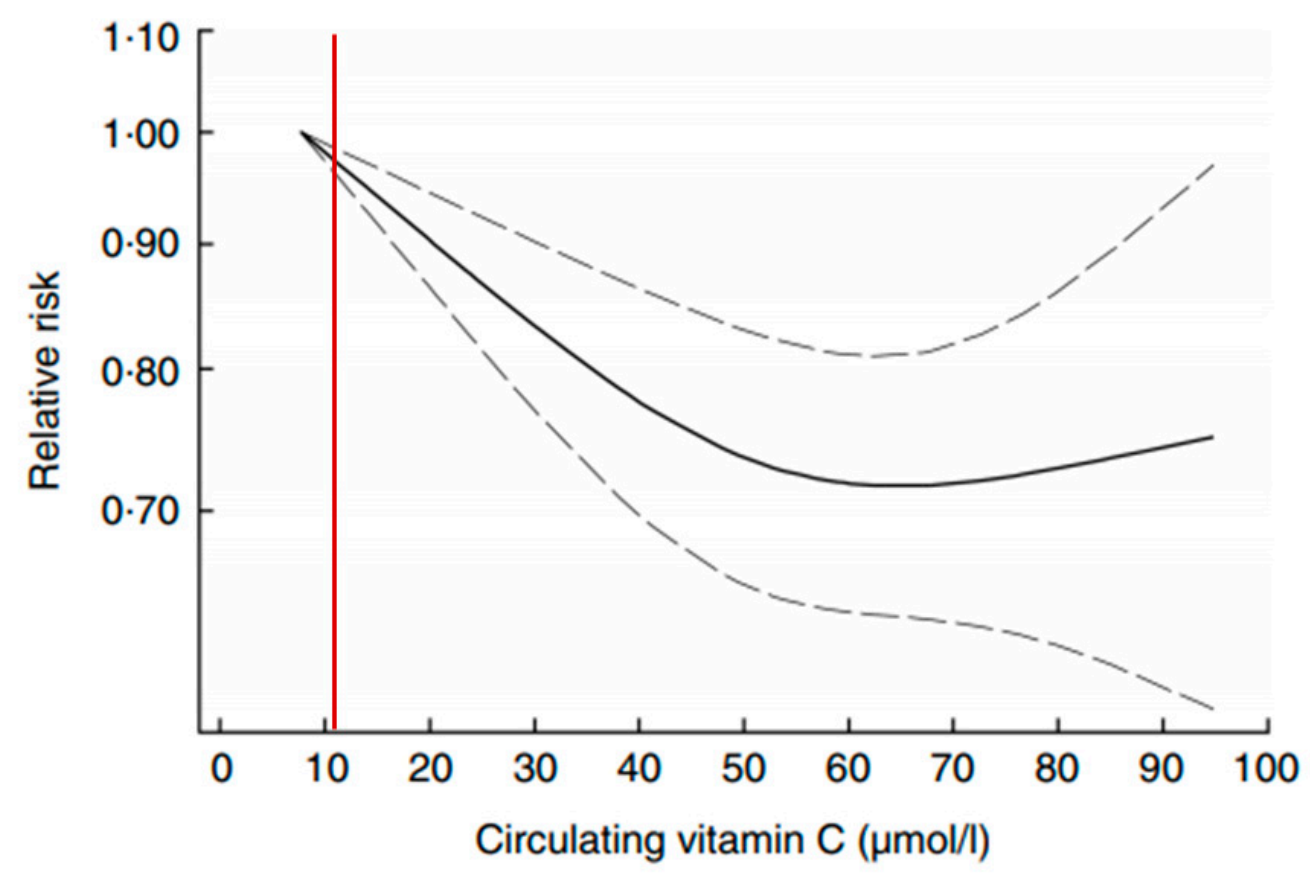

Figure 2. Dose-response association between vitamin C concentration and risk of total CVD mortality with 95\% CI from 6 studies with 45,040 participants and 2992 cases. From [56]. Vertical red line indicates vitamin $\mathrm{C}$ deficiency, i.e., blood ascorbic acid < $11.4 \mu \mathrm{mol} / \mathrm{L}$, used in setting DRI [28].

\section{Establishing Lutein and EPA + DHA DRIs and Updating Vitamin K and Mg DRIs}

Some nutrients are essential to prevent deficiency diseases and for normal growth and maintenance, e.g., intrauterine growth, childhood development, etc., whereas bioactive compounds in food that are not deemed essential may still help maintain normal cellular structure and function. The Office of Dietary Supplements at the NIH defines bioactive compounds as constituents of foods or dietary supplements, other than those needed to meet basic nutritional needs, which are responsible for changes in health status; however, currently, dietary bioactive ingredients have almost no role in public policy [58]. A scientific framework has been proposed [59-61] requiring a safety evaluation for every ingredient before establishing recommended intakes and a UL.

The RDAs for Vitamin D and calcium, updated in 2011, were the first nutrients to have DRIs updated with a goal beyond a straightforward prevention of deficiency, i.e., an intended goal to maintain the health of a tissue/organ, i.e., skeletal health [26]. Subsequently, the US and Canadian governments sought nominations in 2013 for nutrients that should undergo the DRI process. Sixteen nutrients were nominated: arachidonic acid, choline, chromium, docosahexaenoic acid (DHA), eicosapentaenoic acid (EPA), fiber (specifically viscous fibers and fermentable fibers), magnesium, niacin, potassium, protein, saturated fat, sodium, stearic acid, vitamin B6, vitamin E, and zinc [62]. The prioritized nutrients were sodium, omega-3 fatty acids, vitamin E, and magnesium [63]. DRIs for sodium and potassium have been updated [64] and the scientific evidence for a riboflavin DRI is being scanned [65]. Arising from two conference reports, nine criteria have been identified for a food ingredient that has not been defined as a nutrient, i.e., a dietary bioactive, to qualify for DRI evaluation (Table 2) [60,61]. 
Table 2. Criteria to qualify for DRI evaluation and inclusion in DGAs. Adapted from [61].

\begin{tabular}{|c|c|}
\hline Criterion & Additional Information \\
\hline Commonly used definition of the substance & Definition matches method of analysis \\
\hline $\begin{array}{l}\text { A method of analyzing the substance } \\
\text { consistent with the definition }\end{array}$ & Preferably validated by multi-center analysis \\
\hline $\begin{array}{l}\text { Database of the amount of the nutrient or } \\
\text { bioactive in food (and supplements) }\end{array}$ & Preferably global and regularly updated \\
\hline Prospective Cohort studies & $\begin{array}{c}\text { Both sexes and showing relationship between } \\
\text { outcome and dietary intake, or preferably } \\
\text { biochemical or clinical indicator }\end{array}$ \\
\hline $\begin{array}{l}\text { Clinical trials on digestion, absorption, } \\
\text { transport, and excretion of the substance }\end{array}$ & $\begin{array}{l}\text { Important to understand level of intake, factors } \\
\text { affecting absorption, metabolism, and excretion }\end{array}$ \\
\hline Clinical trials on efficacy and dose-response & $\begin{array}{l}\text { Conducted in healthy populations with } \\
\text { bioactive being measured along with accepted } \\
\text { endpoint or biomarker }\end{array}$ \\
\hline Safety data at anticipated level of intake & $\begin{array}{l}\text { Should include data from special populations, } \\
\text { e.g., children, pregnant or lactating women }\end{array}$ \\
\hline $\begin{array}{c}\text { Systematic reviews and/or meta-analyses } \\
\text { showing efficacy }\end{array}$ & $\begin{array}{c}\text { Required by IOM for setting DRI and inclusion } \\
\text { in DGA recommendations }\end{array}$ \\
\hline A plausible biological explanation for efficacy & Not required but nevertheless important \\
\hline
\end{tabular}

This report will now discuss two dietary bioactive compounds and two nutrients as case studies deserving of consideration for DRIs. Lutein was selected because, as a bioactive compound, it fulfills all nine criteria in Table 2 [66]. The second bioactive compounds, the omega-3 fatty acids EPA + DHA, and magnesium, were selected because they were prioritized by the Joint Canada-US Dietary Reference Intakes Working Group [63]. Vitamin $\mathrm{K}$ was chosen based on new data and requests to review vitamin $\mathrm{K}$ dietary recommendations $[67,68]$

\section{Lutein}

Lutein, lycopene, zeaxanthin, $\beta$-cryptoxanthin, and $\alpha$-carotene were excluded from DRI consideration in the late 1990s because of a lack of (1) comprehensive food composition data, (2) population-based dietary intake data, (3) limited information on absorption and metabolism, and (4) insufficient data on biological actions [28,69]. Since then, lutein has been proposed for DRI review [66].

Lutein is a chemically defined xanthophyll, a class of oxygen-containing carotenoids commonly found in nature [70] with a standard reference material [71] and a publicly available database [72]. Lutein accumulates in the macular pigment in the retina and is the predominant carotenoid found in the human brain [73-76]. Factors known to affect carotenoid bioavailability, i.e., blood and tissue concentrations, include: (1) food-based factors, e.g., co-consumption of lipids, food processing, and molecular structure, (2) environmental factors, e.g., prescription drugs, smoking and alcohol consumption, and (3) individual physiological factors, e.g., age, body composition, hormonal fluctuations, and variation in genes associated with carotenoid absorption and metabolism [77]. The typical US lutein intake is $1-2 \mathrm{mg} /$ day, well below the $10 \mathrm{mg}$ lutein supplemented daily in AgeRelated Eye Disease Study (AREDS) 2 [78]. There is strong evidence that up to $20 \mathrm{mg} /$ day is safe and efficacious, and doses up to $40 \mathrm{mg}$ /day have been used in studies ranging from 7 days to 24 months without reported adverse effects [66]. Extreme manipulations in primate lutein intake (xanthophyll-free diet) affect retinal pigment epithelial cells that play an important role in the visual cycle, i.e., modifying and recycling retinoids, photoreceptor materials, and nutrient transport from the blood to photoreceptor cells [79]. Foveal protection from blue light is absent in primates fed xanthophyll-free diets but evident 
after supplementation with lutein and zeaxanthin [80]. Lutein from foods or supplements increases blood levels and macular pigment optical density (MPOD) in the retina in a dose-dependent manner (Figure 3) [81-83].

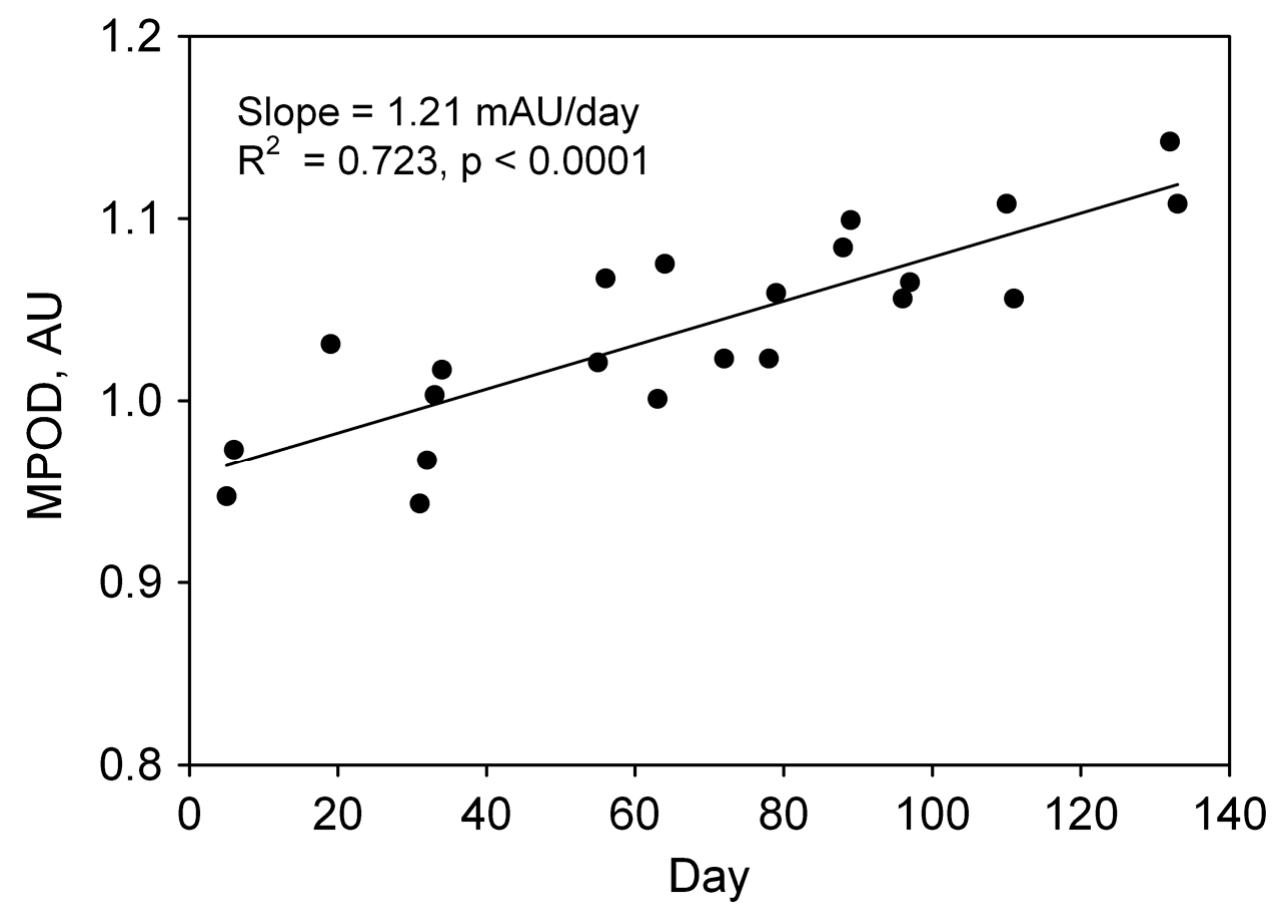

Figure 3. Serum lutein and macular pigment optical density (MPOD). Rate of change of MPOD (milliAbsorbance units) as a function of fractional change in serum lutein concentration (plateau value minus pre-supplementation value, divided by pre-supplementation value). Data from 46 healthy subjects randomly assigned to $0,5,10$, and $20 \mathrm{mg}$ of free, unesterified lutein in soft-shell gelatin capsules and whose standard deviations in the rates of change of MPOD were $<0.250$. From [83].

MPOD is related to static indicators of visual performance, such as glare and contrast sensitivity, and dynamic measures of visual performance such as the critical flicker fusion threshold [84-86]. MPOD is also related to measures of cognitive function such as verbal fluency, memory, processing speed and accuracy [76]. MPOD was significantly associated with select auditory thresholds in young healthy adults [87]. Elevated lutein and zeaxanthin status appears to be associated with diminished risk of cataract [88]. While supplementation with $10 \mathrm{mg}$ lutein and $2 \mathrm{mg}$ zeaxanthin had no effect on advanced age-related macular degeneration (AMD) risk in AREDS, subgroup analysis showed a beneficial effect in patients with the lowest baseline intake of these carotenoids [89]. A recent systematic review and meta-analysis of six longitudinal cohort studies concluded that dietary intake of lutein and zeaxanthin was not significantly associated with a decrease in risk of developing early AMD but an increased intake of these carotenoids may be protective against late AMD [90]. A meta-analysis of 22 publications found a positive correlation of MPOD with measures of visual function, i.e., contrast sensitivity, photostress recovery, and glare disability [91]. A steroidogenic acute regulatory family protein, i.e., StARD3, has been identified in primates and subsequently identified as a human retinal lutein-binding protein [92]. In summary, there is evidence to support the promulgation of lutein DRI to achieve MPOD levels that are associated with healthy visual and brain function.

\section{Eicosapentaenoic Acid (EPA) and Docosahexaenoic Acid (EPA)}

The omega-3 (n-3) long-chain polyunsaturated fatty acids EPA (C20:5n-3) and DHA (C22:6n-3) can be produced endogenously by humans from $\alpha$-linolenic acid (ALA; C18:3n-3) [93] and metabolized into hundreds of active forms, e.g., resolvins, leukotrienes, prostaglandins, 
thromboxane, poxytrins, maresins, etc. [94]. Biological mechanisms of action have been established and reviewed elsewhere [95]. The rate of biosynthesis from ALA is low and insufficient to meet the physiological demands for EPA + DHA [96,97]. EPA + DHA are structurally integrated via phospholipid molecules into surface membranes of heart, cardiovascular, brain and visual cells, affecting signaling pathways and function [98]. The primary sources of EPA + DHA are fish and shellfish with n-3 long-chain polyunsaturated fat intake varying from 0.023 to $0.435 \%$ of energy globally [99]. An official method to quantify fatty acids in foods is available [100] and publicly available databases exist [72]. US dietary intake studies estimate n-3 long chain intake, i.e., EPA + DHA + estimated EPA-equivalents, of $0.17 \mathrm{mg} /$ day with $>90 \%$ of the population consuming $<0.5 \mathrm{~g} /$ day with $\sim 6 \%$ of the population reporting n-3 fatty acid supplement use [101].

In 2005, the Institute of Medicine concluded there was insufficient evidence to establish DRIs for EPA and DHA [30]. The 2005 DGA recommended eating 2 servings of fatty fish per week to obtain omega-3 fatty acids, i.e., EPA and DHA, which is associated with a reduction in risk of mortality from cardiovascular disease, and it noted that "other sources of EPA and DHA may provide similar benefits" [102]. In addition to recommending that $\sim 10 \%$ of the Acceptable Macronutrient Distribution Range for ALA can be consumed as EPA and/or DHA ( 100 mg/d),Kris-Etherton et al. (2009) [103] called for the National Academies to establish DRIs for individual long-chain ( $\geq 20$ carbons or greater) n-3 fatty acids. A technical committee of experts from the International Life Sciences Institute of North America proposed a DRI for EPA + DHA be established between 250 and $500 \mathrm{mg}$ /day [104]. A review of 40 randomized controlled trials with EPA/DHA supplementation in 135,267 participants found EPA + DHA supplementation to be an effective lifestyle strategy for coronary heart disease prevention, and the protective effect probably increases with dosage, especially the use of 1000-2000 mg/day [105]. The EPA + DHA content of food products is available [106]. Digestion and absorption are understood. Colipase-dependent pancreatic lipase hydrolyzes triglyceride and phospholipids, with ethyl esters being digested by a bile salt-dependent carboxyl ester lipase that is affected by co-consumption of a fat-containing meal $[107,108]$. Dietary lipid structure does not seem to modify the incorporation of EPA and DHA found in blood [109,110]. EPA + DHA are transported into RBC and cardiac tissue at similar rates [111] and have half-life estimates in humans of 1,67 and 22 hours for ALA, EPA, and DHA, respectively [112]. Long-chain n-3 fatty acids are sequestered in brain [113-115], eye [116], and adipose [117].

$\mathrm{EPA}+\mathrm{DHA}$ content of RBC, the Omega-3 Index, reflects long-term intake of EPA + DHA [118] and is inversely associated with risk of CHD [119,120]. The concentration of EPA + DHA in RBC can be accurately estimated from the fatty acid composition of other blood fractions [121,122]. Best practices for the design, laboratory analysis and reporting of clinical trials involving fatty acids have been published [123]. As EPA + DHA intake increases, blood EPA + DHA concentrations increase in a dose-dependent manner [124,125]. A meta-analysis of 21 randomized clinical trials (RCT) involving high-dose EPA + DHA prescription drugs found doses of 1.8-4 g/day for intervals ranging from 8 to 261 weeks to be safe and well-tolerated [126]. DHA supplementation, alone or in combination with EPA, is associated with improved episodic memory in adults with mild memory complaints [127]. Higher plasma EPA and DHA status are associated with lower total mortality, especially CHD death, in older adults (Figure 4) [128,129]. 


\section{Eicosapentaenoic acid (EPA)}

\section{Docosapentaenoic acid}
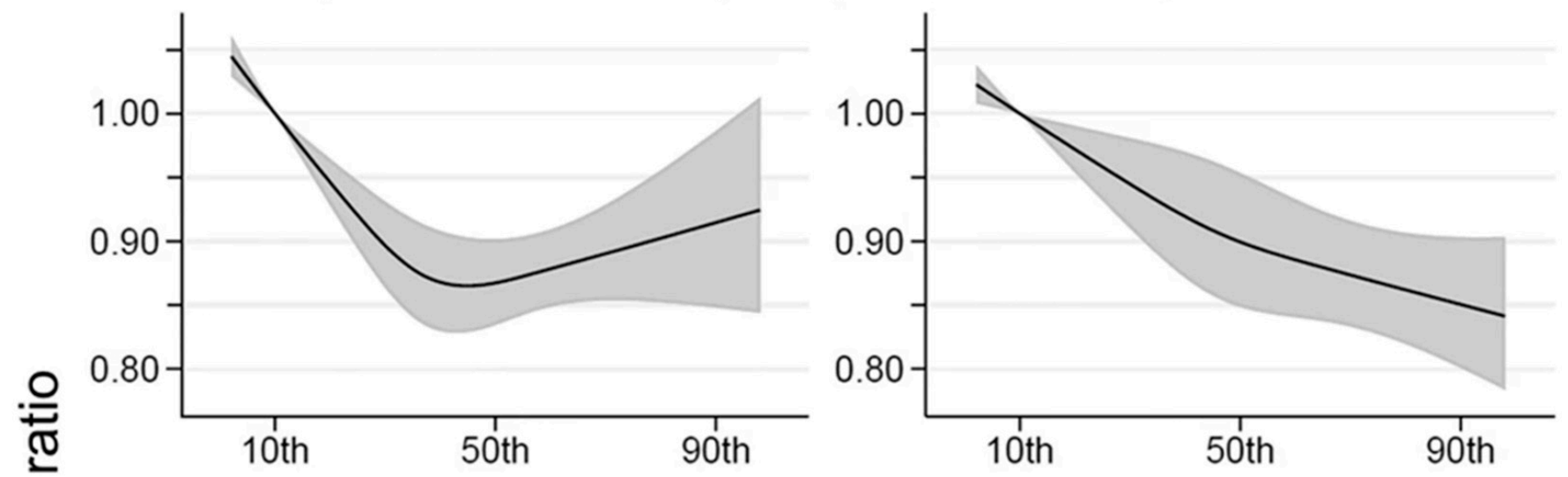

Docosahexaenoic acid (DHA)
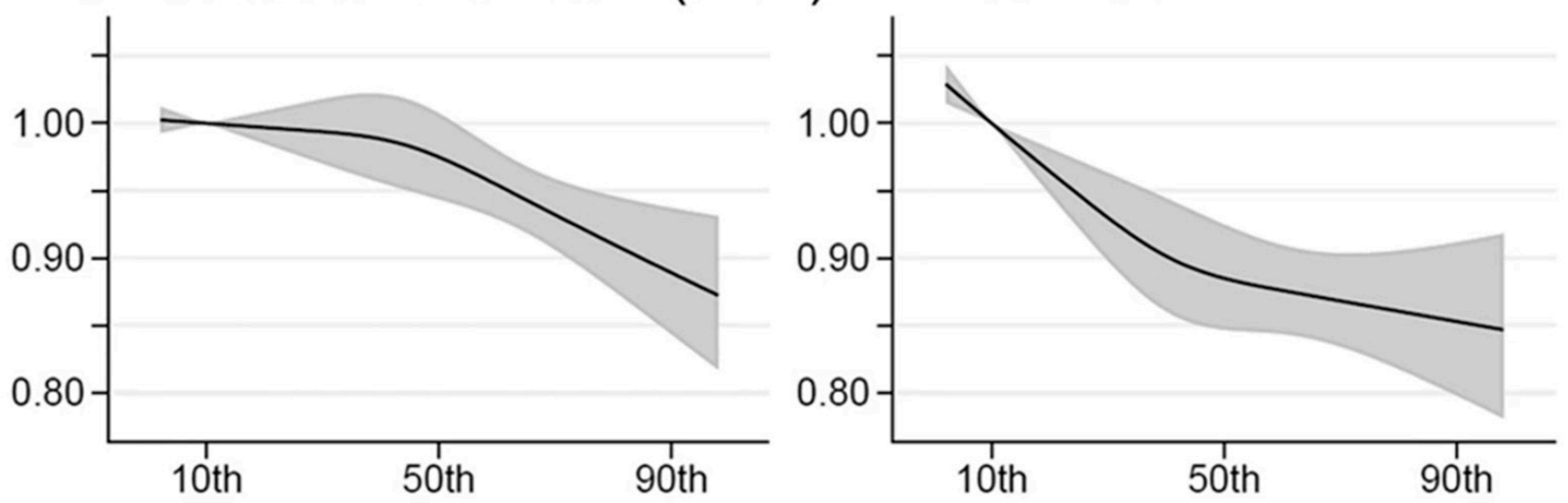

\section{Cohort-specific quantiles}

Figure 4. Multivariate-adjusted relationship of blood long-chain, omega-3 fatty acids with all-cause mortality. De novo pooled analysis using data from 17 prospective cohort studies with a median 16 y follow-up, 15,720 deaths among 42,466 participants, and an average baseline age of 65 years. The solid lines and shaded area represent the best estimates and $95 \%$ $\mathrm{CI}$, respectively. The 10th percentile was selected as a reference level $(\mathrm{HR}=1)$ and the $\mathrm{x}$-axis depicts 5 th to 95 th percentiles. Potential nonlinearity was identified for EPA $(p=0.0004)$ but not for others $(p>0.05)$. All HRs are adjusted for age, sex, race, field center, body-mass index, education, occupation, marital status, smoking, physical activity, alcohol intake, prevalent diabetes, hypertension, and dyslipidemia, self-reported general health, and the sum of circulating 6 polyunsaturated fatty acids (linoleic plus arachidonic acids). From [129].

A meta-analysis of omega-3 supplementation trials reported an $8 \%$ reduced risk of myocardial infarction and CHD death [130] but not all RCTs or prospective cohort studies have shown a consistent response [131,132]. In an extensive Cochrane review of the effects of omega-3 fatty acid supplementation (without consideration of blood EPA + DHA levels) on cardiovascular health, the authors reported moderate- and low-certainty evidence that increasing long-chain omega-3s slightly reduces risk of coronary heart disease mortality and events, and reduces serum triglycerides (evidence mainly from supplement trials) [133]. Two meta-analyses report reduced relative risk per 1 standard deviation increase in blood fatty acid level for CHD: EPA + DHA (0.75; 95\% CI: 0.62-0.89) [134] and EPA (0.91; 95\% CI: 0.82-1.00) [135]. Indeed, the International Society for the Study of Fatty Acids and Lipids has recommended that all research studies include measurement of n-3 fatty acids at baseline and follow-up [136]. In a prospective cohort study with 1625 deaths (total, CVD, 
and CHD), collected between 1992 and 2008 and a total of 30,929 person-years, individuals in the highest plasma EPA + DHA quintile lived an average of 2.22 more years after age 65 years than did those in the lowest quintile [128]. The Women's Health Initiative Memory Study, a prospective cohort, found an $8 \%$ reduction in risk of death with higher blood EPA + DHA levels [137]. A meta-analysis of prospective observational studies found that individuals with an Omega-3 Index $>8 \%$ were at $35 \%$ lower risk for death from any cause than those with an Omega-3 Index $<4 \%$ [138]. Circulating DHA concentrations were significantly lower in individuals with mild cognitive impairment relative to controls [139]. Higher blood EPA + DHA levels appear to protect people exposed to ambient particulate matter air pollutants as they have muted blood fibrinogen responses [140] and greater brain volumes [141]. In conclusion, the growth in evidence associating higher EPA + DHA levels with beneficial health outcomes coupled with updated safety data is sufficient to justify setting EPA + DHA DRIs to achieve target blood ranges.

\section{Vitamin K}

Vitamin $\mathrm{K}$ is a fat-soluble vitamin that exists naturally in multiple forms: 1 ) vitamin $\mathrm{K}_{1}$ consisting of a phylloquinone with a 2-methyl-1,4-napthoquinone ring with a phytyl group at the 3-position, and 2) vitamin $\mathrm{K}_{2}$, or menaquinone (MK) forms where the phytyl group is replaced with 4-10 repeating isoprenoid units, MK-4 through MK-10, respectively [142,143]. Vitamins $K_{1}$ and $K_{2}$ were isolated in 1939 [144]. Vitamin $K_{1}$ is found in green leafy vegetables and vegetables oils [72], MK-4 through MK-6 are present in low levels in animal based foods, e.g., some cheeses and chicken meat, and MK-7 is found in fermented soybeans (natto) where it is formed by bacteria during fermentation [143]. Vitamin K is also produced by gut microbiota but their contribution to vitamin K status is unclear [68]. In 1935, vitamin $\mathrm{K}$ was identified as an antihemorrhagic factor and a convenient analytical method for food was published in 1936 [145]. All forms of vitamin K serve as a cofactor for posttranslational carboxylation of specific protein-bound glutamyl residues to $\gamma$-carboxyglutamate (Gla) that are essential for the formation of several coagulation factors (II, VII, IX and X) and inhibitors (proteins C and S) in the liver [146,147]. Gla proteins not related to blood clotting are osteocalcin (OC, synthesized in bone) and matrix Gla protein (MGP, primarily synthesized in cartilage and the vessel wall) [148]. Low vitamin K intake is associated with low bone mineral density increased fracture risk, and increased risk of CVD and mortality [148]. Higher levels of under-carboxylated osteocalcin $(u \mathrm{cOC})$ are a marker of hip fracture in elderly women [149]. Supplementation with vitamin $K_{2}(375 \mu \mathrm{g}$ MK-7/day) decreased ucOC after 3 months and preserved trabecular bone structure at the tibia at 12 months [150]. Based primarily on indicators of coagulation and dietary phylloquinone $\left(\mathrm{K}_{1}\right)$ intake, AIs for vitamin $\mathrm{K}$ were established [27]. Vitamin $\mathrm{K}$ consumption from food or supplements is not associated with adverse effects, including toxicity, in humans or animals with the caveat that there was insufficient high vitamin $\mathrm{K}$ intake data in humans to establish a UL (highest recorded intake was $367 \mu \mathrm{g} /$ day) [27]. Since the DRIs were issued, a protective role for vitamin $K$, specifically vitamin $K_{2}$, in bone health has emerged $[151,152]$ and it has been noted that the AI may be insufficient for full carboxylation of all vitamin K-dependent proteins [143]. The essential role of MGP in inhibiting arterial calcification was confirmed in rats treated with warfarin to induce rapid arterial calcification [153]. Using this rat model, increasing dietary vitamin $\mathrm{K}$ intake increases vitamin $\mathrm{K}$ concentrations in the aorta and blunted cardiovascular calcification $[153,154]$. At the tissue level, vitamin $\mathrm{K}_{1}$ is converted to MK-4 [155] with vitamin $\mathrm{K}_{2}$ being effective at lower doses than $\mathrm{K}_{1}$ [156]. Supplementation with vitamin $\mathrm{K}$ has been shown to block age-related arterial stiffening in postmenopausal women [157] and retard postmenopausal bone loss [158,159]. Often prescribed to prevent thomboembolisms, vitamin $\mathrm{K}$ antagonists interfere with $\gamma$-carboxylation of Gla-proteins in mice [160]. Vascular calcification is a predictor of cardiovascular mortality and $u$ cOC levels and MK-7 supplementation induces a time- and dose-dependent reduction in circulating $u \mathrm{cOC}$, dephospho-uncarboxylated matrix Gla protein (dp-ucMGP) levels in hemodialysis patients [161]. A meta-analysis of 19 RCTs with postmenopausal women with or without 
osteoporosis found that vitamin $\mathrm{K}_{2}$ supplementation decreased $u \mathrm{COC}$ and increased $\mathrm{OC}$, indicating a positive effect on bone metabolism and reduced the incidence of fractures with a risk ratio of 0.63 [162]. The authors concluded vitamin $\mathrm{K}_{2}$ supplementation was effective for maintaining vertebral and forearm bone mineral density (BMD) in postmenopausal women with osteoporosis but there was no significant effect in postmenopausal women without osteoporosis. Calcification of the coronary artery has been identified as a marker of increased CVD risk in humans [163-165]. In a double-blind RCT, MK-7 supplementation of healthy, prepubertal children resulted in increased blood MK-7 concentrations and OC (vs. controls) but bone markers and coagulation parameters did not differ between treatments [166]. In an RCT with 244 postmenopausal women using $180 \mu \mathrm{g}$ MK-7 per day for 3 years, vitamin K2 supplementation decreased dp-ucMGP values by $50 \%$ (vs. controls) and significantly improved vascular stiffness indicators [157]. Subsequently, MK7 supplementation has been reported to increase circulating c-OC and $u$ cOC levels [167]. In a meta-analysis of 13 controlled RCTs and 14 longitudinal trials, vitamin K supplementation was associated with a $9 \%$ reduction in vascular calcification, $44 \%$ reduction in dp-ucMGP, and $12 \%$ reduction in $u \mathrm{cOC}$, all indicators pointing to a reduction in vascular disease and CVD mortality (Figure 5) [168].

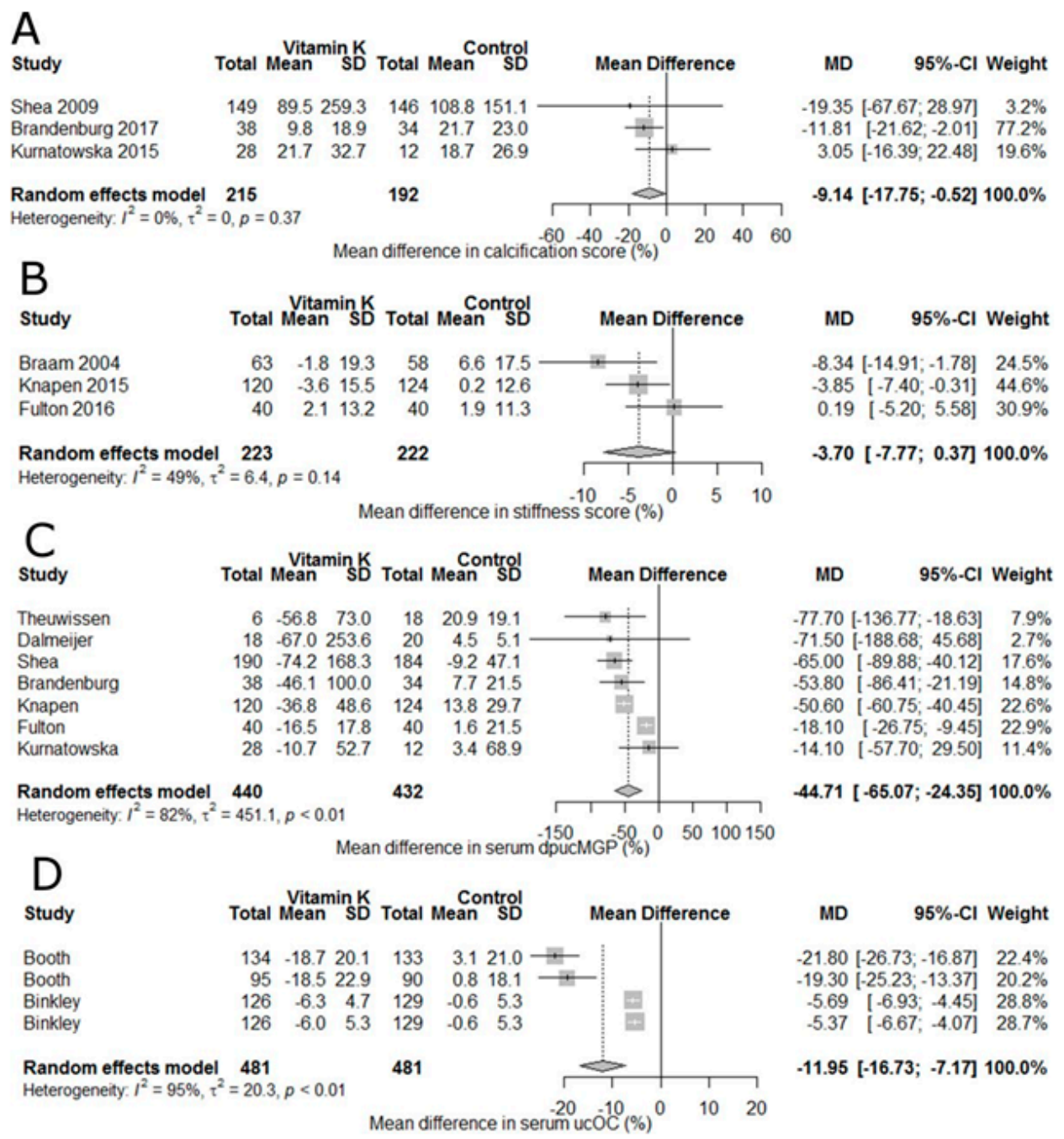

Figure 5. Forest plots showing the effect of vitamin K supplementation. (A) \% change in vascular calcification. (B) Vascular stiffness. (C) Serum dephospho-uncarboxylated matrix Gla protein (dp$u \mathrm{cMGP}$ ). (D) serum uncarboxylated osteocalcin ( $u \mathrm{cOC})$. Data are presented as mean \% difference and $95 \%$ CI. From [168]. 
A meta-analysis of 11 prospective cohort studies concluded that high blood dp-ucMGP level, an indicator of vitamin K insufficiency, is an independent predictor of cardiovascular disease and mortality [169]. In conclusion, recent insights into the metabolism of vitamin $\mathrm{K}_{1}$ and $\mathrm{K}_{2}$ forms and their metabolites as biomarkers of disease risk and new evidence linking dietary vitamin $\mathrm{K}$ in food or supplement with maintaining normal bone, blood clotting, and cardiovascular function justify a systematic review of the scientific literature, reevaluation of the vitamin $\mathrm{KAI}$, and possibly dividing the DRI into vitamin $\mathrm{K}_{1}$ and $\mathrm{K}_{2}$ forms [67].

\section{Magnesium (Mg)}

$\mathrm{Mg}$, a required cofactor for over 600 enzyme reactions and $50 \%$ of total body $\mathrm{Mg}$ content found in bone [170], has an EAR derived from intake data and limited balance studies [46]. Apatite-bound Mg in bone cannot be mobilized even under extreme depletion, whereas $\mathrm{Mg}$ absorbed to the surface of mineral crystals can be mobilized during hypomagnesemia [171]. Most men and women are not consuming the Mg EAR from food alone, i.e., green vegetables, nuts, seeds, dried beans, whole grains, and meats, and supplements containing $\mathrm{Mg}$ contribute importantly to total dietary intake $[172,173]$. $\mathrm{Mg}$ has been repeatedly identified as an under-consumed nutrient $[16,17,102,174]$ with a greater percentage of non-Hispanic Black people $<\mathrm{EAR}$ for $\mathrm{Mg}$, calcium, and phosphorus than non-Hispanic white people across all ages [175]. Older obese adults have a greater risk of inadequate $\mathrm{Mg}$ intake than their healthy-weight counterparts [176]. Thirty percent of Mexican-American and non-Hispanic Black women have dietary Mg intake $<$ EAR with the percentage varying by body weight status [177]. Mg is generally absorbed from the gut as an ion through transcellular and paracellular pathways [178]. Due to the importance of passive paracellular $\mathrm{Mg}^{2+}$ absorption, the amount of $\mathrm{Mg}$ in the gut is the major factor controlling absorption [178]. Other factors affecting $\mathrm{Mg}$ requirement include body mass, obesity, background diet (calcium, type of fiber, vitamin E and selenium), and oxidative stress [179]. Mg is essential in the metabolism of vitamin D as low dietary Mg intake can alter vitamin D-parathyroid hormone balance [180] and large doses of vitamin D can deplete $\mathrm{Mg}$ [181]. Evidence from 27 different balance studies in 243 healthy individuals found age and sex do not appear to affect urinary Mg excretion [182]. Some think the 1997 DRIs were set too high and lower levels have been proposed [182], whereas others think the proposed levels did not consider numerous physiological factors such as total body weight $[179,183]$.

Cellular Mg levels are strictly regulated and eight cation channels have been identified with transient receptor potential melastatin (TRPM7) being the most selective channel for $\mathrm{Mg}$ in the heart, blood vessels, lungs, liver, brain, intestine and spleen, whereas TRMP6 is mainly responsible for regulating total body magnesium level via the kidney and intestines [170]. The serum total $\mathrm{Mg}$ concentration (STMC) normal reference range used clinically is $0.85-0.96 \mathrm{mmol} / \mathrm{L}(1.70-1.92 \mathrm{mEq} / \mathrm{L}$ or $2.06-2.33 \mathrm{mg} / \mathrm{dL})[184]$ and is derived from values measured in a healthy population (NHANES I) [185] rather than the relationship between serum $\mathrm{Mg}$ and clinical outcomes which can manifest $<0.85 \mathrm{mmol} / \mathrm{L}$ [186]. While overt $\mathrm{Mg}$ deficiency is not common, almost every organ system is affected by the availability of $\mathrm{Mg}[186,187]$. Strong correlations of Mg concentration with increased risk of several chronic diseases indicate that $\mathrm{Mg}$ status should be assessed more routinely [188], not only to reassess DRI chronic disease endpoints [189] but also for optimization of nutritional status and body stores.

Using baseline STMC data from 14,353 participants (NHANES 1 1971-1975) with a median follow-up of 28.6 y (until 2011), very low STMC $(<0.7 \mathrm{mmol} / \mathrm{L})$ was significantly associated with a $34 \%$ increased risk of all-cause mortality $(\mathrm{HR}=1.34 ; 1.02-1.77)$ (Figure 6) and trended significance for cancer ( $\mathrm{HR}=1.39 ; 0.83-2.32), \mathrm{CVD}(\mathrm{HR}=1.28 ; 0.81-2.02)$ and stroke (HR $=2.55 ; 1.18-5.48)$ [190]. A cross-sectional, population-based survey (20122013) of 5561 participants living in Canada found $9.5-16.6 \%$ of adults and $15.8-21.8 \%$ of adolescents surveyed had a STMC $<0.75 \mathrm{nmol} / \mathrm{L}$ and STMC was negatively associated 
with diabetes, BMI, serum glucose, serum insulin, $\mathrm{HbA}_{1 \mathrm{C}}$, and HOMA-IR [191]. Having diabetes was associated with $0.04-0.07 \mathrm{mmol} / \mathrm{L}$ lower STMC compared to not having diabetes [191].

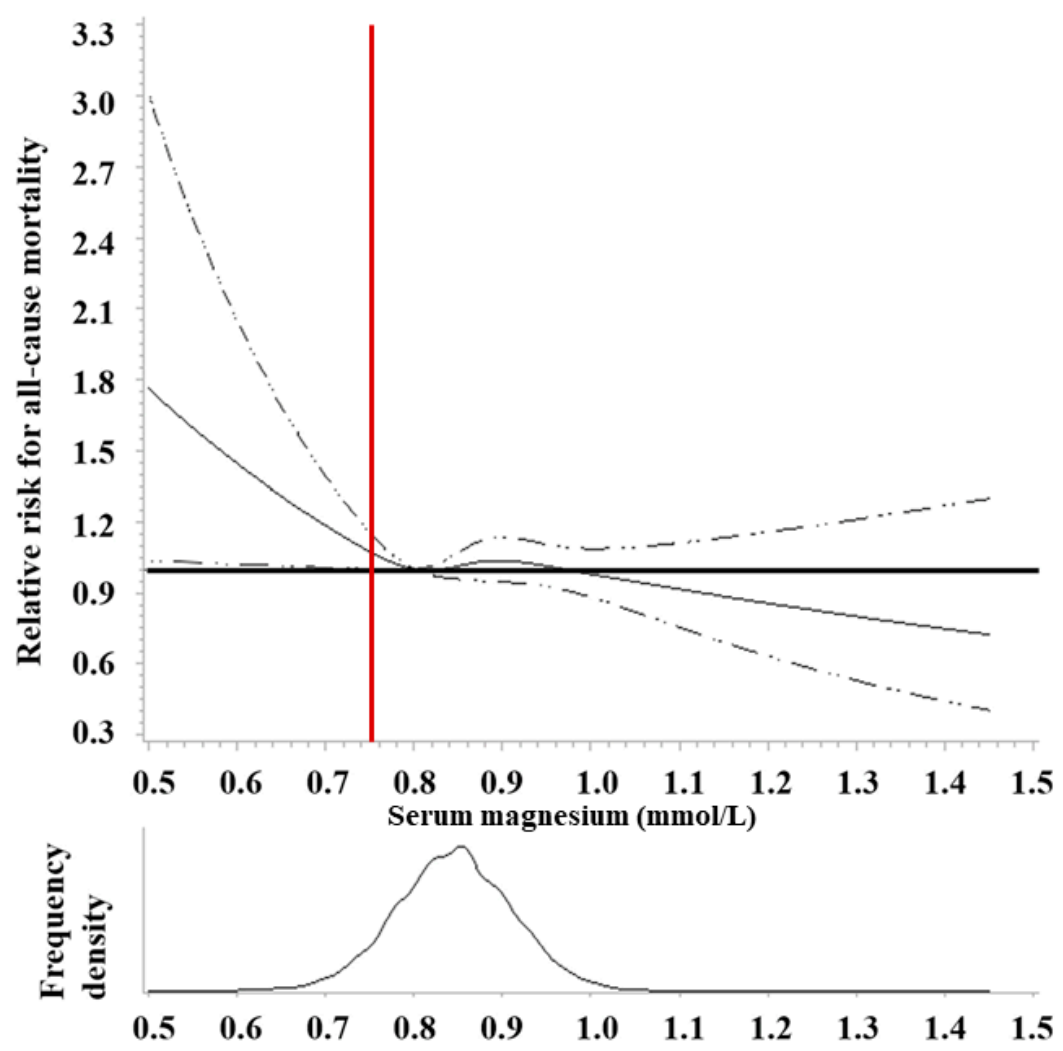

Figure 6. Adjusted hazard ratios of serum magnesium with all-cause mortality in the US adult population (NHANES I 1971-2011). The solid curve is HR calculated by restricted cubic splines with knots at serum $\mathrm{Mg}$ levels of $0.73,0.82,0.87$, and $0.96 \mathrm{mmol} / \mathrm{L}$, a reference $\mathrm{HR}=1$ set at $0.80 \mathrm{mmol} / \mathrm{L}$, and adjusted using weighted Cox regression model for age, sex, race/ethnicity, education, family income, smoking, alcohol, physical activity, BMI, history of diabetes, hypertension, and vitamin and/or mineral supplement uses. From [190]. Vertical red line indicates magnesium depletion cutoff, i.e., serum $\mathrm{Mg}$ concentration $<0.75 \mathrm{mmol} / \mathrm{L}$, used in setting DRI [46].

In summary, in addition to the established evidence linking Mg with healthy bones, there is emerging evidence of a relationship between STMC and risk of NCD. Current DRIs need to be updated to consider physiological factors, i.e., body mass and obesity, and assess the interaction of other dietary factors, such as the amount of calcium, protein, dietary fiber, antioxidants, vitamin $\mathrm{E}$ and selenium. This will require updating food databases [72] to maintain accurate estimates of $\mathrm{Mg}$, sodium, potassium and calcium content in food. The lack of a standardized biomarker and STMC reference range with appropriate cutoffs to accurately assess $\mathrm{Mg}$ status remains a challenge. With only $0.3 \%$ of total body $\mathrm{Mg}$ in serum, the combination of STMC, urinary Mg excretion and dietary Mg history adjusted for body weight may be the best means to assess Mg status [186].

\section{Personalizing Nutrition Guidance and Improving Population-Based Assessment}

Precision health depends upon the integration of dietary history, supplement use, demographics, behavior, lifestyle, social, cultural, economic, occupational, and environmental factors. It also encompasses personal information, i.e., age, sex, nutrition-related biomarkers, genetics, microbiome, etc. The DRIs provide a set of reference values that are useful in planning and assessing the adequacy of nutrient intakes of healthy individuals. Nutrient intake assessments provide insight into individual dietary patterns and inform 
nutritional advice, i.e., personalizing guidance, but it can take days of intake data to predict an individual's usual intake, even months for nutrients such as vitamin A [192]. Dietary intake records may still not reflect nutritional status because of reporting inaccuracies, outdated and/or incomplete food and supplement databases because of the rapid evolution of commodity, food and supplement offerings, and a lack of bioavailability information. Technology is streamlining dietary data collection, analysis and interpretation and diagnostic devices measuring validated biomarkers and metabolic profiles can help assess the availability of essential nutrients and dietary bioactive components to cells, tissues and organs [193]. The proliferation of smartphone dietary apps, direct-to-consumer sale of personalized formulations with re-order reminders, wearable devices, and submission of biological samples raises ethical and privacy considerations. Nevertheless, personalized or precision nutrition approaches will benefit from the validation of biomarkers and metabolic health, standardization of methods of analysis, consensus on reference ranges defining deficient, insufficient, adequate, and optimal status with consideration for an individual's sex, age, life stage, nutrigenomics, microbiomics, and the algorithms that bring these factors together [194].

With objective measures of nutritional status, e.g., RBC folate, uncarboxylated vitamin K-dependent proteins, or serum $25(\mathrm{OH}) \mathrm{D}$ concentrations, researchers can characterize relationships between objective, biochemical measures of nutritional status and functional outcomes to define nutrient ranges for vitamins, minerals and bioactive compounds that support healthy cellular, organ, and tissue function, i.e., optimize health. The greatest risk of false-negative or false-positive tests is not in the optimal range; risk is greatest at the tails of the distribution surrounding the cutpoints being used to diagnose a deficiency disease or nutritional excess. Finally, by understanding the nature of nutritional status and functional outcome relationships, e.g., $25(\mathrm{OH}) \mathrm{D}$ and skeletal health, it is possible to define optimal ranges and use these data to update or establish DRIs for the general healthy public (Figure 1). The adoption of point-of-care diagnostic tools by health care professionals will enable accurate assessment of the nutritional status of individuals, personalization of dietary guidance, and follow-up to determine if a deficiency, insufficiency, or excess has been remediated. These same biomarker or surrogate endpoint measures can be used by public health professionals to accurately assess nutrition interventions [195]. Point-of-care nutrition monitoring diagnostic tools are often invasive, i.e., finger stick, but advances in wearable and saliva-based technologies are likely. While the adoption of point-of-care diagnostic technologies may be more costly than measuring dietary intake, manufacturing economies of scale will decrease cost and increase availability. Most importantly, by identifying individuals and communities at risk of undernutrition and overnutrition, the risk of nutrition-related communicable diseases may be reduced.

\section{Conclusions}

Underconsumption of some essential nutrients and food bioactive components, especially from food alone, is still a concern in the US population, even though dietary guidance recognizes the contributions from food fortification and vitamin and mineral dietary supplements. The DGA aim to provide recommendations for healthy eating to promote health and prevent disease, and are updated periodically to incorporate current scientific evidence, yet recommended intakes still rely on DRIs established decades ago. Moreover, US DRIs define dietary intakes needed to maintain nutritional status at levels that prevent vitamin/mineral deficiency diseases; DRIs should be revised to be based on intake levels that provide cells, organs and tissues with access to adequate amounts of micronutrients (and bioactives) to function optimally, i.e., healthy structure/function outcomes. It is recommended that DRIs for vitamin $\mathrm{K}$ and $\mathrm{Mg}$ be updated and DRIs be established for lutein and EPA + DHA. Precision or personalized nutrition offers unprecedented opportunities to assess the nutritional status of healthy individuals and to personalize individual dietary guidance. The field will be further advanced by investments in the research, development, evaluation and validation of innovative algorithms and 
technologies to better assess dietary intake from food and dietary supplements, nutritional status, metabolomic fingerprints, microbiome profiles, and metagenomic measures across age, sex, and physiological (growth, pregnancy, lactation) classifications. Continual updating of food and supplement composition databases will be required. The adoption of diagnostic devices, including the measurement of nutritional biomarkers, is a foundation of precision health. Objective measures of nutritional status, e.g., RBC folate, uncarboxylated vitamin $\mathrm{K}$-dependent proteins, or serum $25(\mathrm{OH}) \mathrm{D}$ concentrations, will allow for the evaluation of interventions ranging from mandatory food enrichment and fortification to the distribution and use of dietary supplements on health outcomes. The data generated via precision nutrition on nutritional status and physiological function will be important to guide public health policy on federal nutrition programs.

Author Contributions: M.I.M. wrote the manuscript. As presenters, J.B.B., R.B.C., M.E., J.W.E.J., W.S.H., E.J.J., R.C.P., and L.J.S. contributed content and citations to the manuscript. As Vice-Chair of CRN's Senior Scientific Advisory Council, S.H.M. helped plan and chaired the two-day event. D.R. moderated the discussion. All authors have read and agreed to the published version of the manuscript.

Funding: The Council for Responsible Nutrition (CRN) hosted the symposium where speakers participated remotely. Speakers received an honorarium for their participation. M.I.M. received financial support to write the manuscript and CRN is supporting publication costs.

Institutional Review Board Statement: Not applicable.

Informed Consent Statement: Not applicable.

Acknowledgments: This article is based on information presented and ideas discussed at the Council for Responsible Nutrition (www.crnusa.org) symposium "Challenges and Opportunities for Public Health Recommendations Around Dietary Supplements" held on 13-14 October 2020. The event was organized and supported by the Council for Responsible Nutrition (CRN) (www.crnusa.org), a trade association representing dietary supplement and functional food manufacturers and ingredient suppliers. CRN receives support primarily from its industry membership.

Conflicts of Interest: M.I.M. serves on the Board of Directors of the American Society for Nutrition and consults with Council for Responsible Nutrition; Church \& Dwight; DSM Nutritional Products; Fatty Acid Research Institute; International Life Sciences Institute, North America; McCormick; OmegaQuant Analytics; PepsiCo; and VitaMe Technologies. J.B.B. reports service on scientific advisory boards of AdvoCare, California Prune Board, California Walnut Commission, Church \& Dwight, Cranberry Marketing Committee, Guiding Stars Licensing Co., Segterra, and SmartyPants (all outside the submitted work). R.B.C. is a named individual on a submitted FDA petition for a qualified health claim for magnesium and hypertension. M.E. consults for several companies in the nutritional ingredient and supplement sector and is a member of the scientific board of PM International. J.W.E.J. has no conflicts to disclose. W.S.H. holds an interest in OmegaQuant Analytics, a lab that offers omega-3 blood testing. E.J.J. is a principal nutrition scientist at Ocean Spray, Inc., a farmer-owned cooperative that grows and sells cranberry products. S.H. Mitmesser is employed by Pharmavite, a dietary supplement manufacturer. R.C.P. is the CEO of a consulting firm for growers, food and ingredient manufacturers, and scientific organizations, the Executive Director of the National Seasoning Manufacturers Association, Inc., and Adjunct Instructor of Food Laws at Rutgers University. $\mathrm{He}$ is also on advisory boards with equity in a number of food companies and health IT start-ups. D.R. is employed by OmniActive Health Technologies, a natural ingredients supplier to the dietary supplements, functional food, and beverage industries. L.J.S. received institutional grants from Bayer, Boehringer Ingelheim, NattoPharma, and ImmunoDiagnostic Systems. None of the authors declares any conflict of interest in providing their solely scientific opinion for this review.

\section{References}

1. U.S. Department of Agriculture; U.S. Department of Health and Human Services. 1980 Dietary Guidelines for Americans; Agricultural Research Service: Washington, DC, USA, 1980; p. 18.

2. U.S. Department of Agriculture; U.S. Department of Health and Human Services. Dietary Guidelines for Americans, 2020-2025; Agricultural Research Service: Washington, DC, USA, 2020; p. 164. 
3. U.S. Department of Agriculture; U.S. Department of Health and Human Services. 1985 Dietary Guidelines for Americans; Agricultural Research Service: Washington, DC, USA, 1985; p. 13.

4. CDC. Recommendations for the Use of Folic Acid to Reduce the Number of Cases of Spina Bifida and Other Neural Tube Defects. MMWR 1992, 41, 1-7.

5. FDA. Food Labeling: Revision of the Nutrition and Supplement Facts Label. Fed. Regist. 2016, 81, 33741-33999.

6. FDA. Food Labeling: Revision of the Nutrition and Supplement Facts Labels and Serving Sizes of Foods That Can Reasonably Be Consumed at One Eating Occasion; Dual-Column Labeling; Updating, Modifying, and Establishing Certain Reference Amounts Customarily Consumed; Serving Size for Breath Mints; and Technical Amendments; Extension of Compliance Dates. Available online: https: / / www.federalregister.gov / documents/2018/05/04/2018-09476/food-labeling-revision-of-the-nutrition-andsupplement-facts-labels-and-serving-sizes-of-foods-that (accessed on 10 May 2019).

7. FDA. Food Labeling: Requirements for Nutrient Content Claims for Dietary Supplements of Vitamins, Minerals, Herbs, and Other Similar Nutritional Substances. Fed. Regist. 1994, 59, 354-395.

8. FDA. Food Labeling: Health Claims and Label Statements; Folate and Neural Tube Defects. Fed. Regist. 1993, 58, 53254-53295.

9. FDA. Food Standards: Amendment of Standards of Identity for Enriched Grain Products to Require Addition of Folic Acid. Fed. Regist. 1996, 61, 8781-8796.

10. FDA. Food Additives Permitted for Direct Addition to Food for Human Consumption: Folic Acid. Fed. Regist. 2016, 81, 22176-22183.

11. Hatch, O.G. S.784 Dietary Supplement Health and Education Act of 1994. Available online: https://www.congress.gov/103/ bills/s784/BILLS-103s784enr.pdf (accessed on 17 December 2020).

12. U.S. Department of Agriculture; U.S. Department of Health and Human Services. 1995 Dietary Guidelines for Americans. Available online: https:/ / www.dietaryguidelines.gov/sites/default/files/2019-05/1995\%20Dietary\%20Guidelines\%20for\%20 Americans.pdf (accessed on 18 October 2020).

13. U.S. Department of Agriculture; U.S. Department of Health and Human Services. 2000 Dietary Guidelines for Americans. Available online: https:/ / health.gov/sites/default/files/2020-01/DGA2000.pdf (accessed on 18 October 2020).

14. Jahns, L.; Davis-Shaw, W.; Lichtenstein, A.H.; Murphy, S.P.; Conrad, Z.; Nielsen, F. The History and Future of Dietary Guidance in America. Adv. Nutr. 2018, 9, 136-147. [CrossRef] [PubMed]

15. Obbagy, J.E.; Blum-Kemelor, D.M.; Essery, E.V.; Lyon, J.M.; Spahn, J.M. USDA Nutrition Evidence Library: Methodology Used to Identify Topics and Develop Systematic Review Questions for the Birth-to-24-Mo Population. Am. J. Clin. Nutr. 2014, 99, 692S-696S. [CrossRef]

16. U.S. Department of Agriculture; U.S. Department of Health and Human Services. 2015-2020 Dietary Guidelines for Americans; Agricultural Research Service: Washington, DC, USA, 2015; p. 144.

17. Dietary Guidelines Advisory Committee. Scientific Report of the 2020 Dietary Guidelines Advisory Committee: Advisory Report to the Secretary of Agriculture and the Secretary of Health and Human Services; Agricultural Research Service: Washington, DC, USA, 2020.

18. NIH. Notice of Intent to Publish a Funding Opportunity Announcement for Nutrition for Precision Health, Powered by the All of Us Research Program: Metabolomics and Clinical Assays Center (U24). Available online: https://grants.nih.gov/grants/guide/ notice-files/NOT-RM-21-002.html (accessed on 17 November 2020).

19. O'Dell, B.L.; Sunde, R.A. Handbook of Nutritionally Essential Mineral Elements; Marcel Dekker, Inc.: New York, NY, USA, 1997; ISBN 0-8247-9312-9.

20. Hou, Y.; Yin, Y.; Wu, G. Dietary Essentiality of "Nutritionally Non-Essential Amino Acids" for Animals and Humans. Exp. Biol. Med. 2015, 240, 997-1007. [CrossRef]

21. Vickery, H.B.; Schmidt, C.L.A. The History of the Discovery of the Amino Acids. Chem. Rev. 1931, 9, 169-318. [CrossRef]

22. Eggersdorfer, M.; Laudert, D.; Létinois, U.; McClymont, T.; Medlock, J.; Netscher, T.; Bonrath, W. One Hundred Years of Vitamins: A Success Story of the Natural Sciences. Angew. Chem. Int. Ed. 2012, 51, 12960-12990. [CrossRef] [PubMed]

23. National Research Council. Recommended Dietary Allowances; National Academies Press: Washington, DC, USA, 1941; p. 13286, ISBN 978-0-309-22234-1.

24. Institute of Medicine. Dietary Reference Intakes: The Essential Guide to Nutrient Requirements; The National Academies Press: Washington, DC, USA, 2006; ISBN 978-0-309-15742-1.

25. National Research Council (U.S.). Recommended Dietary Allowances, 10th ed.; The National Academies Press: Washington, DC, USA, 1989; p. 1349, ISBN 978-0-309-04633-6.

26. Institute of Medicine (Ed.) Dietary Reference Intakes for Calcium, Vitamin D; The National Academies Press: Washington, DC, USA, 2011; ISBN 978-0-309-16394-1.

27. Institute of Medicine (U.S.). Dietary Reference Intakes for Vitamin A, Vitamin K, Arsenic, Boron, Chromium, Copper, Iodine, Iron, Manganese, Molybdenum, Nickel, Silicon, Vanadium, and Zinc; The National Academies Press: Washington, DC, USA, 2001.

28. Institute of Medicine. Dietary Reference Intakes for Vitamin C, Vitamin E, Selenium, and Carotenoids; The National Academies Press: Washington, DC, USA, 2000.

29. Institute of Medicine. Dietary Reference Intakes for Thiamin, Riboflavin, Niacin, Vitamin B6, Folate, Vitamin B12, Pantothenic Acid, Biotin, and Choline; The National Academies Press: Washington, DC, USA, 1998.

30. Institute of Medicine. Dietary Reference Intakes for Energy, Carbohydrate, Fiber, Fat, Fatty Acids, Cholesterol, Protein, and Amino Acids (Macronutrients); The National Academies Press: Washington, DC, USA, 2005; ISBN 978-0-309-08525-0. 
31. Biesalski, H.-K.; Dragsted, L.O.; Elmadfa, I.; Grossklaus, R.; Müller, M.; Schrenk, D.; Walter, P.; Weber, P. Bioactive Compounds: Definition and Assessment of Activity. Nutrition 2009, 25, 1202-1205. [CrossRef] [PubMed]

32. Kantor, E.D.; Rehm, C.D.; Du, M.; White, E.; Giovannucci, E.L. Trends in Dietary Supplement Use among US Adults from 1999-2012. JAMA 2016, 316, 1464. [CrossRef]

33. Cowan, A.E.; Jun, S.; Tooze, J.A.; Dodd, K.W.; Gahche, J.J.; Eicher-Miller, H.A.; Guenther, P.M.; Dwyer, J.T.; Moshfegh, A.J.; Rhodes, D.G.; et al. Comparison of 4 Methods to Assess the Prevalence of Use and Estimates of Nutrient Intakes from Dietary Supplements among US Adults. J. Nutr. 2019, nxz306. [CrossRef]

34. Li, J.; Li, X.; Gathirua-Mwangi, W.; Song, Y. Prevalence and Trends in Dietary Supplement Use among US Adults with Diabetes: The National Health and Nutrition Examination Surveys, 1999-2014. BMJ Open Diab. Res. Care. 2020, 8, e000925. [CrossRef]

35. Gahche, J.J.; Bailey, R.L.; Potischman, N.; Dwyer, J.T. Dietary Supplement Use Was Very High among Older Adults in the United States in 2011-2014. J. Nutr. 2017, 147, 1968-1976. [CrossRef] [PubMed]

36. Bailey, R.L.; Gahche, J.J.; Miller, P.E.; Thomas, P.R.; Dwyer, J.T. Why US Adults Use Dietary Supplements. JAMA Intern. Med. 2013, 173, 355. [CrossRef]

37. Bailey, R.L.; Fulgoni, V.L.; Keast, D.R.; Dwyer, J.T. Examination of Vitamin Intakes among US Adults by Dietary Supplement Use. J. Acad. Nutr. Diet. 2012, 112, 657-663. [CrossRef] [PubMed]

38. Bailey, R.L.; Pac, S.G.; Fulgoni, V.L.; Reidy, K.C.; Catalano, P.M. Estimation of Total Usual Dietary Intakes of Pregnant Women in the United States. JAMA Netw. Open 2019, 2, e195967. [CrossRef]

39. Blumberg, J.; Frei, B.; Fulgoni, V.; Weaver, C.; Zeisel, S. Contribution of Dietary Supplements to Nutritional Adequacy in Various Adult Age Groups. Nutrients 2017, 9, 1325. [CrossRef] [PubMed]

40. Cowan, A.E.; Jun, S.; Tooze, J.A.; Eicher-Miller, H.A.; Dodd, K.W.; Gahche, J.J.; Guenther, P.M.; Dwyer, J.T.; Potischman, N.; Bhadra, A.; et al. Total Usual Micronutrient Intakes Compared to the Dietary Reference Intakes among U.S. Adults by Food Security Status. Nutrients 2019, 12, 38. [CrossRef]

41. Troesch, B.; Hoeft, B.; McBurney, M.; Eggersdorfer, M.; Weber, P. Dietary Surveys Indicate Vitamin Intakes below Recommendations Are Common in Representative Western Countries. Br. J. Nutr. 2012, 108, 692-698. [CrossRef]

42. CDC. Poor Nutrition. Available online: https://www.cdc.gov/chronicdisease/resources/publications/factsheets/nutrition.htm (accessed on 18 October 2020).

43. CDC. Chronic Diseases in America. Available online: https://www.cdc.gov/chronicdisease/pdf/infographics/chronic-diseaseH.pdf (accessed on 26 May 2021).

44. American Chemical Society. American Chemical Society National Historic Chemical Landmarks. The Discovery of Vitamin C by Albert Szent-Gyorgyi. Available online: https://www.acs.org/content/acs/en/education/whatischemistry/landmarks/ szentgyorgyi.html (accessed on 19 October 2020).

45. WHO. WHO Guideline on the Use of Ferritin Concentrations to Assess Iron Status in Individual Populations; World Health Organization: Geneva, Switzerland, 2020.

46. Institute of Medicine (Ed.) Dietary Reference Intakes for Calcium, Phosphorus, Magnesium, Vitamin D, and Fluoride; The National Academies Press: Washington, DC, USA, 1997; ISBN 978-0-309-06350-0.

47. Bischoff-Ferrari, H.A.; Giovannucci, E.; Willett, W.C.; Dietrich, T.; Dawson-Hughes, B. Estimation of Optimal Serum Concentrations of 25-Hydroxyvitamin D for Multiple Health Outcomes. Am. J. Clin. Nutr. 2006, 84, 18-28. [CrossRef]

48. Phinney, K.W.; Bedner, M.; Tai, S.S.-C.; Vamathevan, V.V.; Sander, L.C.; Sharpless, K.E.; Wise, S.A.; Yen, J.H.; Schleicher, R.L.; Chaudhary-Webb, M.; et al. Development and Certification of a Standard Reference Material for Vitamin D Metabolites in Human Serum. Anal. Chem. 2012, 84, 956-962. [CrossRef]

49. Van Schoor, N.M.; Heymans, M.W.; Lips, P. Vitamin D Status in Relation to Physical Performance, Falls and Fractures in the Longitudinal Aging Study Amsterdam-A Reanalysis of Previous Findings Using Standardized Serum 25-Hydroxyvitamin D Values. J. Steroid Biochem. Mol. Biol. 2018, 177, 255-260. [CrossRef]

50. Pan, K.; Tu, R.; Yao, X.; Zhu, Z. Associations between Serum Calcium, 25(OH)D Level and Bone Mineral Density in Adolescents. Adv. Rheumatol. 2021, 61, 16. [CrossRef]

51. Teshome, A.; Adane, A.; Girma, B.; Mekonnen, Z.A. The Impact of Vitamin D Level on COVID-19 Infection: Systematic Review and Meta-Analysis. Front. Public Health 2021, 9, 624559. [CrossRef] [PubMed]

52. Hodges, R.E.; Hood, J.; Canham, J.E.; Sauberlich, H.E.; Baker, E.M. Clinical Manifestations of Ascorbic Acid Deficiency in Man. Am. J. Clin. Nutr. 1971, 24, 432-443. [CrossRef] [PubMed]

53. Carr, A.C.; Lykkesfeldt, J. Discrepancies in Global Vitamin C Recommendations: A Review of RDA Criteria and Underlying Health Perspectives. Crit. Rev. Food Sci. Nutr. 2020, 1-14. [CrossRef] [PubMed]

54. Carr, A.C.; Bozonet, S.M.; Pullar, J.M.; Simcock, J.W.; Vissers, M.C. Human Skeletal Muscle Ascorbate Is Highly Responsive to Changes in Vitamin C Intake and Plasma Concentrations. Am. J. Clin. Nutr. 2013, 97, 800-807. [CrossRef]

55. Loria, C.M.; Klag, M.J.; Caulfield, L.E.; Whelton, P.K. Vitamin C Status and Mortality in US Adults. Am. J. Clin. Nutr. 2000, 72, 139-145. [CrossRef]

56. Jayedi, A.; Rashidy-Pour, A.; Parohan, M.; Zargar, M.S.; Shab-Bidar, S. Dietary and Circulating Vitamin C, Vitamin E, $\beta$-Carotene and Risk of Total Cardiovascular Mortality: A Systematic Review and Dose-Response Meta-Analysis of Prospective Observational Studies. Public Health Nutr. 2019, 22, 1872-1887. [CrossRef] 
57. Rowe, S.; Carr, A.C. Global Vitamin C Status and Prevalence of Deficiency: A Cause for Concern? Nutrients 2020, 12, 2008. [CrossRef]

58. Weaver, C.M. Bioactive Foods and Ingredients for Health. Adv. Nutr. 2014, 5, 306S. [CrossRef] [PubMed]

59. Wallace, T.C.; Blumberg, J.B.; Johnson, E.J.; Shao, A. Dietary Bioactives: Establishing a Scientific Framework for Recommended Intakes. Adv. Nutr. Int. Rev. J. 2015, 6, 1-4. [CrossRef] [PubMed]

60. Lupton, J.R.; Atkinson, S.A.; Chang, N.; Fraga, C.G.; Levy, J.; Messina, M.; Richardson, D.P.; van Ommen, B.; Yang, Y.; Griffiths, J.C.; et al. Exploring the Benefits and Challenges of Establishing a DRI-like Process for Bioactives. Eur. J. Nutr. 2014, 53, S1-S9. [CrossRef] [PubMed]

61. Lupton, J.R.; Blumberg, J.B.; L'Abbe, M.; LeDoux, M.; Rice, H.B.; von Schacky, C.; Yaktine, A.; Griffiths, J.C. Nutrient Reference Value: Non-Communicable Disease Endpoints-A Conference Report. Eur. J. Nutr. 2016, 55, 1-10. [CrossRef]

62. U.S. Department of Health and Human Services. Nutrient Assessment for DRI Review. Available online: https://health.gov/ our-work/food-nutrition/dietary-reference-intakes-dris/nutrient-assessment-dri-review (accessed on 20 October 2020).

63. MacFarlane, A.J.; Cogswell, M.E.; de Jesus, J.M.; Greene-Finestone, L.S.; Klurfeld, D.M.; Lynch, C.J.; Regan, K.; Yamini, S.; Joint Canada-US Dietary Reference Intakes Working Group. A Report of Activities Related to the Dietary Reference Intakes from the Joint Canada-US Dietary Reference Intakes Working Group. Am. J. Clin. Nutr. 2019, 109, 251-259. [CrossRef] [PubMed]

64. National Academies of Sciences, Engineering, and Medicine. Dietary Reference Intakes for Sodium and Potassium; The National Academies Press: Washington, DC, USA, 2019; p. 25353. ISBN 978-0-309-48834-1.

65. National Academies of Sciences, Engineering, and Medicine. Evidence Scanning for Riboflavin. Available online: https: //www.nationalacademies.org/our-work/evidence-scanning-for-riboflavin (accessed on 20 October 2020).

66. Ranard, K.M.; Jeon, S.; Mohn, E.S.; Griffiths, J.C.; Johnson, E.J.; Erdman, J.W. Dietary Guidance for Lutein: Consideration for Intake Recommendations Is Scientifically Supported. Eur. J. Nutr. 2017, 56, 37-42. [CrossRef] [PubMed]

67. Akbulut, A.C.; Pavlic, A.; Petsophonsakul, P.; Halder, M.; Maresz, K.; Kramann, R.; Schurgers, L. Vitamin K2 Needs an RDI Separate from Vitamin K1. Nutrients 2020, 12, 1852. [CrossRef] [PubMed]

68. Turck, D.; Bresson, J.-L.; Burlingame, B.; Dean, T.; Fairweather-Tait, S.; Heinonen, M.; Hirsch-Ernst, K.I.; Mangelsdorf, I.; McArdle, H.J.; Naska, A.; et al. Dietary Reference Values for Vitamin K. EFSA J. 2017, 15, e04780. [CrossRef] [PubMed]

69. Institute of Medicine. Dietary Reference Intakes: Proposed Definition and Plan for Review of Dietary Antioxidants and Related Compounds; The National Academies Press: Washington, DC, USA, 1998; p. 6252. ISBN 978-0-309-06187-2.

70. Mortensen, A. Carotenoids and Other Pigments as Natural Colorants. Pure Appl. Chem. 2006, 78, 1477-1491. [CrossRef]

71. Thomas, J.B.; Duewer, D.L.; Mugenya, I.O.; Phinney, K.W.; Sander, L.C.; Sharpless, K.E.; Sniegoski, L.T.; Tai, S.S.; Welch, M.J.; Yen, J.H. Preparation and Value Assignment of Standard Reference Material 968e Fat-Soluble Vitamins, Carotenoids, and Cholesterol in Human Serum. Anal. Bioanal. Chem. 2012, 402, 749-762. [CrossRef] [PubMed]

72. U.S. Department of Agriculture. F.S.R.G. WWEIA/NHANES and FNDDS—List of Nutrients/Food Components (Unit): USDA ARS. Available online: https:/ / www.ars.usda.gov/northeast-area/beltsville-md-bhnrc/beltsville-human-nutrition-researchcenter/food-surveys-research-group/docs/wweianhanes-and-fndds-list-of-nutrientsfood-components-unit/ (accessed on 1 November 2020).

73. Johnson, E.J.; Vishwanathan, R.; Johnson, M.A.; Hausman, D.B.; Davey, A.; Scott, T.M.; Green, R.C.; Miller, L.S.; Gearing, M.; Woodard, J.; et al. Relationship between Serum and Brain Carotenoids, $\alpha$-Tocopherol, and Retinol Concentrations and Cognitive Performance in the Oldest Old from the Georgia Centenarian Study. J. Aging Res. 2013, 2013, 951786. [CrossRef] [PubMed]

74. Vishwanathan, R.; Kuchan, M.J.; Sen, S.; Johnson, E.J. Lutein and Preterm Infants with Decreased Concentrations of Brain Carotenoids. J. Pediatr. Gastroenterol. Nutr. 2014, 59, 659-665. [CrossRef]

75. Erdman, J.; Smith, J.; Kuchan, M.; Mohn, E.; Johnson, E.; Rubakhin, S.; Wang, L.; Sweedler, J.; Neuringer, M. Lutein and Brain Function. Foods 2015, 4, 547-564. [CrossRef]

76. Stringham, J.M.; Johnson, E.J.; Hammond, B.R. Lutein across the Lifespan: From Childhood Cognitive Performance to the Aging Eye and Brain. Curr. Dev. Nutr. 2019, 3, nzz066. [CrossRef]

77. Moran, N.E.; Mohn, E.S.; Hason, N.; Erdman, J.W.; Johnson, E.J. Intrinsic and Extrinsic Factors Impacting Absorption, Metabolism, and Health Effects of Dietary Carotenoids. Adv. Nutr. 2018, 9, 465-492. [CrossRef]

78. Chew, E.Y.; Clemons, T.; SanGiovanni, J.P.; Danis, R.; Domalpally, A.; McBee, W.; Sperduto, R.; Ferris, F.L. The Age-Related Eye Disease Study 2 (AREDS2). Opthalmology 2012, 119, 2282-2289. [CrossRef]

79. Leung, I.Y.-F.; Sandstrom, M.M.; Zucker, C.L.; Neuringer, M.; Snodderly, D.M. Nutritional Manipulation of Primate Retinas, II: Effects of Age, n-3 Fatty Acids, Lutein, and Zeaxanthin on Retinal Pigment Epithelium. Investig. Ophthalmol. Vis. Sci. 2004, 45, 3244. [CrossRef]

80. Barker, F.M.; Snodderly, D.M.; Johnson, E.J.; Schalch, W.; Koepcke, W.; Gerss, J.; Neuringer, M. Nutritional Manipulation of Primate Retinas, V: Effects of Lutein, Zeaxanthin, and n-3 Fatty Acids on Retinal Sensitivity to Blue-Light-Induced Damage. Investig. Ophthalmol. Vis. Sci. 2011, 52, 3934-3942. [CrossRef]

81. Böhm, V.; Lietz, G.; Olmedilla-Alonso, B.; Phelan, D.; Reboul, E.; Bánati, D.; Borel, P.; Corte-Real, J.; de Lera, A.R.; Desmarchelier, C.; et al. From Carotenoid Intake to Carotenoid Blood and Tissue Concentrations-Implications for Dietary Intake Recommendations. Nutr. Rev. 2020, nuaa008. [CrossRef] [PubMed] 
82. Rosenthal, J.M.; Kim, J.; de Monastario, F.; Thompson, D.J.S.; Bone, R.A.; Landrum, J.T.; de Moura, F.F.; Khachik, F.; Chen, H.; Schleicher, R.L.; et al. Dose-Ranging Study of Lutein Supplementation in Persons Aged 60 Years or Older. Investig. Ophthalmol. Vis. Sci. 2006, 47, 5227. [CrossRef]

83. Bone, R.A.; Landrum, J.T. Dose-Dependent Response of Serum Lutein and Macular Pigment Optical Density to Supplementation with Lutein Esters. Arch. Biochem. Biophys. 2010, 504, 50-55. [CrossRef] [PubMed]

84. Renzi, L.M.; Hammond, B.R. The Relation between the Macular Carotenoids, Lutein and Zeaxanthin, and Temporal Vision: Macular Pigment and Temporal Vision. Opthalmol. Physiol. Opt. 2010, 30, 351-357. [CrossRef] [PubMed]

85. Obana, A.; Tanito, M.; Gohto, Y.; Okazaki, S.; Gellermann, W.; Bernstein, P.S. Changes in Macular Pigment Optical Density and Serum Lutein Concentration in Japanese Subjects Taking Two Different Lutein Supplements. PLoS ONE 2015, 10, e0139257. [CrossRef]

86. Machida, N.; Kosehira, M.; Kitaichi, N. Clinical Effects of Dietary Supplementation of Lutein with High Bio-Accessibility on Macular Pigment Optical Density and Contrast Sensitivity: A Randomized Double-Blind Placebo-Controlled Parallel-Group Comparison Trial. Nutrients 2020, 12, 2966. [CrossRef] [PubMed]

87. Wong, J.C.; Kaplan, H.S.; Hammond, B.R. Lutein and Zeaxanthin Status and Auditory Thresholds in a Sample of Young Healthy Adults. Nutr. Neurosci. 2017, 20, 1-7. [CrossRef] [PubMed]

88. Weikel, K.A.; Garber, C.; Baburins, A.; Taylor, A. Nutritional Modulation of Cataract. Nutr. Rev. 2014, 72, 30-47. [CrossRef] [PubMed]

89. Age-Related Eye Disease Study 2 Research Group. Lutein + Zeaxanthin and Omega-3 Fatty Acids for Age-Related Macular Degeneration: The Age-Related Eye Disease Study 2 (AREDS2) Randomized Clinical Trial. JAMA 2013, 309, 2005-2015. [CrossRef]

90. Ma, L.; Dou, H.-L.; Wu, Y.-Q.; Huang, Y.-M.; Huang, Y.-B.; Xu, X.-R.; Zou, Z.-Y.; Lin, X.-M. Lutein and Zeaxanthin Intake and the Risk of Age-Related Macular Degeneration: A Systematic Review and Meta-Analysis. Br. J. Nutr. 2012, 107, 350-359. [CrossRef]

91. Johnson, E.J.; Avendano, E.E.; Mohn, E.S.; Raman, G. The Association between Macular Pigment Optical Density and Visual Function Outcomes: A Systematic Review and Meta-Analysis. Eye 2020. [CrossRef] [PubMed]

92. Li, B.; Vachali, P.; Frederick, J.M.; Bernstein, P.S. Identification of StARD3 as a Lutein-Binding Protein in the Macula of the Primate Retina. Biochemistry 2011, 50, 2541-2549. [CrossRef] [PubMed]

93. Salem, N.; Wegher, B.; Mena, P.; Uauy, R. Arachidonic and Docosahexaenoic Acids Are Biosynthesized from Their 18-Carbon Precursors in Human Infants. Proc. Natl. Acad. Sci. USA 1996, 93, 49-54. [CrossRef] [PubMed]

94. Gabbs, M.; Leng, S.; Devassy, J.G.; Aukema, H.M. Advances in Our Understanding of Oxylipins Derived from Dietary PUFAs. Adv. Nutr. 2015, 6, 513-540. [CrossRef] [PubMed]

95. Mozaffarian, D.; Wu, J.H.Y. Omega-3 Fatty Acids and Cardiovascular Disease. J. Am. Coll. Cardiol. 2011, 58, 2047-2067. [CrossRef]

96. Burdge, G.C.; Calder, P.C. Conversion of Alpha-Linolenic Acid to Longer-Chain Polyunsaturated Fatty Acids in Human Adults. Reprod. Nutr. Dev. 2005, 45, 581-597. [CrossRef]

97. Chen, C.T.; Bazinet, R.P. $\beta$-Oxidation and Rapid Metabolism, but Not Uptake Regulate Brain Eicosapentaenoic Acid Levels. Prostaglandins Leukot. Essent. Fatty Acids 2015, 92, 33-40. [CrossRef]

98. Ghasemi Fard, S.; Wang, F.; Sinclair, A.J.; Elliott, G.; Turchini, G.M. How Does High DHA Fish Oil Affect Health? A Systematic Review of Evidence. Crit. Rev. Food Sci. Nutr. 2018, 1-44. [CrossRef] [PubMed]

99. Hibbeln, J.R.; Nieminen, L.R.; Blasbalg, T.L.; Riggs, J.A.; Lands, W.E. Healthy Intakes of N-3 and N-6 Fatty Acids: Estimations Considering Worldwide Diversity. Am. J. Clin. Nutr. 2006, 83, 1483S-1493S. [CrossRef] [PubMed]

100. Collison, M.W. Official Methods and Recommended Practices of the AOCS: Fatty Acids in Edible Oils and Fats Official Method C3 1a-13, 7th ed.; American Oil Chemists Society: Urbana, IL, USA, 2017.

101. Richter, C.K.; Bowen, K.J.; Mozaffarian, D.; Kris-Etherton, P.M.; Skulas-Ray, A.C. Total Long-Chain n-3 Fatty Acid Intake and Food Sources in the United States Compared to Recommended Intakes: NHANES 2003-2008. Lipids 2017, 52, 917-927. [CrossRef] [PubMed]

102. U.S. Department of Agriculture; U.S. Department of Health and Human Services. 2005 Dietary Guidelines for Americans. Available online: https:/ / health.gov/sites/default/files/2020-01/DGA2005.pdf (accessed on 26 October 2020).

103. Kris-Etherton, P.M.; Grieger, J.A.; Etherton, T.D. Dietary Reference Intakes for DHA and EPA. Prostaglandins Leukot. Essent. Fat. Acids 2009, 81, 99-104. [CrossRef]

104. Harris, W.S.; Mozaffarian, D.; Lefevre, M.; Toner, C.D.; Colombo, J.; Cunnane, S.C.; Holden, J.M.; Klurfeld, D.M.; Morris, M.C.; Whelan, J. Towards Establishing Dietary Reference Intakes for Eicosapentaenoic and Docosahexaenoic Acids. J. Nutr. 2009, 139, 804S-819S. [CrossRef] [PubMed]

105. Bernasconi, A.A.; Wiest, M.M.; Lavie, C.J.; Milani, R.V.; Laukkanen, J.A. Effect of Omega-3 Dosage on Cardiovascular Outcomes. Mayo Clin. Proc. 2021, 96, 304-313. [CrossRef] [PubMed]

106. U.S. Department of Agriculture. FoodData Central. Available online: https://ndb.nal.usda.gov/fdc-app.html\#/?query=lutein (accessed on 21 October 2020).

107. Maki, K.C. Long-Chain Omega-3 Fatty Acid Bioavailability: Implications for Understanding the Effects of Supplementation on Heart Disease Risk. J. Nutr. 2018, 148, 1701-1703. [CrossRef]

108. West, A.L.; Kindberg, G.M.; Hustvedt, S.O.; Calder, P.C. A Novel Self-Micro-Emulsifying Delivery System Enhances Enrichment of Eicosapentaenoic Acid and Docosahexaenoic Acid after Single and Repeated Dosing in Healthy Adults in a Randomized Trial. J. Nutr. 2018. [CrossRef] [PubMed] 
109. West, A.L.; Burdge, G.C.; Calder, P.C. Lipid Structure Does Not Modify Incorporation of EPA and DHA into Blood Lipids in Healthy Adults: A Randomised-Controlled Trial. Br. J. Nutr. 2016, 116, 788-797. [CrossRef]

110. Yurko-Mauro, K.; Kralovec, J.; Bailey-Hall, E.; Smeberg, V.; Stark, J.G.; Salem, N. Similar Eicosapentaenoic Acid and Docosahexaenoic Acid Plasma Levels Achieved with Fish Oil or Krill Oil in a Randomized Double-Blind Four-Week Bioavailability Study. Lipids Health Dis. 2015, 14, 99. [CrossRef]

111. Metcalf, R.G.; James, M.J.; Gibson, R.A.; Edwards, J.R.; Stubberfield, J.; Stuklis, R.; Roberts-Thomson, K.; Young, G.D.; Cleland, L.G. Effects of Fish-Oil Supplementation on Myocardial Fatty Acids in Humans. Am. J. Clin. Nutr. 2007, 85, 1222-1228. [CrossRef]

112. Pawlosky, R.J.; Hibbeln, J.R.; Novotny, J.A.; Salem, N. Physiological Compartmental Analysis of $\alpha$-Linolenic Acid Metabolism in Adult Humans. J. Lipid Res. 2001, 42, 1257-1265. [CrossRef]

113. Innis, S.M. Essential Fatty Acids in Growth and Development. Progr. Lipid Res. 1991, 30, 39-103. [CrossRef]

114. Innis, S.M. Dietary (n-3) Fatty Acids and Brain Development. J. Nutr. 2007, 137, 855-859. [CrossRef]

115. Arellanes, I.C.; Choe, N.; Solomon, V.; He, X.; Kavin, B.; Martinez, A.E.; Kono, N.; Buennagel, D.P.; Hazra, N.; Kim, G.; et al. Brain Delivery of Supplemental Docosahexaenoic Acid (DHA): A Randomized Placebo-Controlled Clinical Trial. EBioMedicine 2020, 59, 102883. [CrossRef]

116. Johnson, E.J.; Schaefer, E.J. Potential Role of Dietary N-3 Fatty Acids in the Prevention of Dementia and Macular Degeneration. Am. J. Clin. Nutr. 2006, 83, 149S-158S. [CrossRef]

117. Hames, K.C.; Morgan-Bathke, M.; Harteneck, D.A.; Zhou, L.; Port, J.D.; Lanza, I.R.; Jensen, M.D. Very-Long-Chain w-3 Fatty Acid Supplements and Adipose Tissue Functions: A Randomized Controlled Trial. Am. J. Clin. Nutr. 2017, ajcn148114. [CrossRef] [PubMed]

118. Katan, M.B.; Deslypere, J.P.; van Birgelen, A.P.; Penders, M.; Zegwaard, M. Kinetics of the Incorporation of Dietary Fatty Acids into Serum Cholesteryl Esters, Erythrocyte Membranes, and Adipose Tissue: An 18-Month Controlled Study. J. Lipid Res. 1997, 38, 2012-2022. [CrossRef]

119. Harris, W.S.; von Schacky, C. The Omega-3 Index: A New Risk Factor for Death from Coronary Heart Disease? Prev. Med. 2004, 39, 212-220. [CrossRef] [PubMed]

120. Albert, C.M.; Campos, H.; Stampfer, M.J.; Ridker, P.M.; Manson, J.E.; Willett, W.C.; Ma, J. Blood Levels of Long-Chain n-3 Fatty Acids and the Risk of Sudden Death. N. Engl. J. Med. 2002, 346, 1113-1118. [CrossRef]

121. Stark, K.D.; Aristizabal Henao, J.J.; Metherel, A.H.; Pilote, L. Translating Plasma and Whole Blood Fatty Acid Compositional Data into the Sum of Eicosapentaenoic and Docosahexaenoic Acid in Erythrocytes. Prostaglandins Leukot. Essent. Fatty Acids 2016, 104, 1-10. [CrossRef]

122. Hu, X.F.; Sandhu, S.K.; Harris, W.S.; Chan, H.M. Conversion Ratios of N-3 Fatty Acids between Plasma and Erythrocytes: A Systematic Review and Meta-Regression. Br. J. Nutr. 2017, 117, 1162-1173. [CrossRef]

123. Brenna, J.T.; Plourde, M.; Stark, K.D.; Jones, P.J.H.; Lin, Y.-H. Best Practices for the Design, Laboratory Analysis, and Reporting of Trials Involving Fatty Acids. Am. J. Clin. Nutr. 2018, 108, 1-17. [CrossRef]

124. Flock, M.R.; Skulas-Ray, A.C.; Harris, W.S.; Etherton, T.D.; Fleming, J.A.; Kris-Etherton, P.M. Determinants of Erythrocyte Omega-3 Fatty Acid Content in Response to Fish Oil Supplementation: A Dose-Response Randomized Controlled Trial. J. Am. Heart Assoc. 2013, 2, e000513. [CrossRef]

125. Demmelmair, H.; MacDonald, A.; Kotzaeridou, U.; Burgard, P.; Gonzalez-Lamuno, D.; Verduci, E.; Ersoy, M.; Gokcay, G.; Alyanak, B.; Reischl, E.; et al. Determinants of Plasma Docosahexaenoic Acid Levels and Their Relationship to Neurological and Cognitive Functions in PKU Patients: A Double Blind Randomized Supplementation Study. Nutrients 2018, 10, 1944. [CrossRef] [PubMed]

126. Chang, C.-H.; Tseng, P.-T.; Chen, N.-Y.; Lin, P.-C.; Lin, P.-Y.; Chang, J.P.-C.; Kuo, F.-Y.; Lin, J.; Wu, M.-C.; Su, K.-P. Safety and Tolerability of Prescription Omega-3 Fatty Acids: A Systematic Review and Meta-Analysis of Randomized Controlled Trials. Prostaglandins Leukot. Essent. Fatty Acids 2018, 129, 1-12. [CrossRef] [PubMed]

127. Yurko-Mauro, K.; Alexander, D.D.; Elswyk, M.E.V. Docosahexaenoic Acid and Adult Memory: A Systematic Review and Meta-Analysis. PLoS ONE 2015, 10, e0120391. [CrossRef] [PubMed]

128. Mozaffarian, D.; Lemaitre, R.N.; King, I.B.; Song, X.; Huang, H.; Sacks, F.M.; Rimm, E.B.; Wang, M.; Siscovick, D.S. Plasma Phospholipid Long-Chain w-3 Fatty Acids and Total and Cause-Specific Mortality in Older Adults. Ann. Intern. Med. 2013, 158, 515-525. [CrossRef]

129. Harris, W.S.; Tintle, N.L.; Imamura, F.; Qian, F.; Ardisson Korat, A.V.; Marklund, M.; Djoussé, L.; Bassett, J.K.; Carmichael, P.-H.; Chen, Y.-Y.; et al. Blood N-3 Fatty Acid Levels and Total and Cause-Specific Mortality from 17 Prospective Studies. Nat. Commun. 2021, 12, 1-9. [CrossRef] [PubMed]

130. Hu, Y.; Hu, F.B.; Manson, J.E. Marine Omega-3 Supplementation and Cardiovascular Disease: An Updated Meta-analysis of 13 Randomized Controlled Trials Involving 127,477 Participants. J. Am. Heart Assoc. 2019, 8. [CrossRef]

131. Alexander, D.D.; Miller, P.E.; Van Elswyk, M.E.; Kuratko, C.N.; Bylsma, L.C. A Meta-Analysis of Randomized Controlled Trials and Prospective Cohort Studies of Eicosapentaenoic and Docosahexaenoic Long-Chain Omega-3 Fatty Acids and Coronary Heart Disease Risk. Mayo Clin. Proc. 2017, 92, 15-29. [CrossRef]

132. Aung, T.; Halsey, J.; Kromhout, D.; Gerstein, H.C.; Marchioli, R.; Tavazzi, L.; Geleijnse, J.M.; Rauch, B.; Ness, A.; Galan, P.; et al. Associations of Omega-3 Fatty Acid Supplement Use with Cardiovascular Disease Risks: Meta-Analysis of 10 Trials Involving 77,917 Individuals. JAMA Cardiol. 2018, 3, 225. [CrossRef] [PubMed] 
133. Abdelhamid, A.S.; Brown, T.J.; Brainard, J.S.; Biswas, P.; Thorpe, G.C.; Moore, H.J.; Deane, K.H.; Summerbell, C.D.; Worthington, H.V.; Song, F.; et al. Omega-3 Fatty Acids for the Primary and Secondary Prevention of Cardiovascular Disease. Cochrane Database Syst. Rev. 2020. [CrossRef] [PubMed]

134. Chowdhury, R.; Warnakula, S.; Kunutsor, S.; Crowe, F.; Ward, H.A.; Johnson, L.; Franco, O.H.; Butterworth, A.S.; Forouhi, N.G.; Thompson, S.G.; et al. Association of Dietary, Circulating, and Supplement Fatty Acids with Coronary Risk. Ann. Intern. Med. 2014, 160, 398-407. [CrossRef] [PubMed]

135. Del Gobbo, L.C.; Imamura, F.; Aslibekyan, S.; Marklund, M.; Virtanen, J.K.; Wennberg, M.; Yakoob, M.Y.; Chiuve, S.E.; dela Cruz, L.; Frazier-Wood, A.C.; et al. w-3 Polyunsaturated Fatty Acid Biomarkers and Coronary Heart Disease: Pooling Project of 19 Cohort Studies. JAMA Intern. Med. 2016, 176, 1155. [CrossRef] [PubMed]

136. de Groot, R.H.M.; Meyer, B.J. ISSFAL Official Statement Number 6: The Importance of Measuring Blood Omega-3 Long Chain Polyunsaturated Fatty Acid Levels in Research. Prostaglandins Leukot. Essent. Fatty Acids 2020, 157, 1-4. [CrossRef]

137. Harris, W.S.; Luo, J.; Pottala, J.V.; Espeland, M.A.; Margolis, K.L.; Manson, J.E.; Wang, L.; Brasky, T.M.; Robinson, J.G. Red Blood Cell Polyunsaturated Fatty Acids and Mortality in the Women's Health Initiative Memory Study. J. Clin. Lipidol. 2017, 11, 250-259.e5. [CrossRef]

138. Harris, W.S.; Del Gobbo, L.; Tintle, N.L. The Omega-3 Index and Relative Risk for Coronary Heart Disease Mortality: Estimation from 10 Cohort Studies. Atherosclerosis 2017, 262, 51-54. [CrossRef]

139. Hosseini, M.; Poljak, A.; Braidy, N.; Crawford, J.; Sachdev, P. Blood Fatty Acids in Alzheimer's Disease and Mild Cognitive Impairment: A Meta-Analysis and Systematic Review. Ageing Res. Rev. 2020, 60, 101043. [CrossRef]

140. Croft, D. Do Elevated Blood Levels of Omega-3 Fatty Acids Modify Effects of Particulate Air Pollutants on Fibrinogen? Air. Qual. Atmos. Health 2018, 11, 791-799. [CrossRef] [PubMed]

141. Chen, C.; Xun, P.; Kaufman, J.D.; Hayden, K.M.; Espeland, M.A.; Whitsel, E.A.; Serre, M.L.; Vizuete, W.; Orchard, T.; Harris, W.S.; et al. Erythrocyte Omega-3 Index, Ambient Fine Particle Exposure, and Brain Aging. Neurology 2020, 95, e995-e1007. [CrossRef] [PubMed]

142. Schurgers, L.J.; Vermeer, C. Determination of Phylloquinone and Menaquinones in Food. Pathol. Haem. Thromb. 2000, 30, $298-307$. [CrossRef] [PubMed]

143. Shea, M.K.; Booth, S.L. Update on the Role of Vitamin K in Skeletal Health. Nutr. Rev. 2008, 66, 549-557. [CrossRef]

144. McKee, R.W.; Binkley, S.B.; MacCorquodale, D.W.; Thayer, S.A.; Doisy, E.A. The Isolation of Vitamins K1 and K2. J. Am. Chem. Soc. 1939, 61, 1295. [CrossRef]

145. Dam, H.; Schonheyder, F. The Occurrence and Chemical Nature of Vitamin K. Bioch. J. 1936, 30, 897-901. [CrossRef] [PubMed]

146. Suttie, J.W. Synthesis of Vitamin K-dependent Proteins. FASEB J. 1993, 7, 445-452. [CrossRef]

147. Shearer, M.J. Vitamin K Metabolism and Nutriture. Blood Rev. 1992, 6, 92-104. [CrossRef]

148. Schurgers, L.J.; Teunissen, K.J.F.; Hamulyák, K.; Knapen, M.H.J.; Vik, H.; Vermeer, C. Vitamin K-Containing Dietary Supplements: Comparison of Synthetic Vitamin K1 and Natto-Derived Menaquinone-7. Blood 2007, 109, 3279-3283. [CrossRef]

149. Szulc, P.; Chapuy, M.C.; Meunier, P.J.; Delmas, P.D. Serum Undercarboxylated Osteocalcin Is a Marker of the Risk of Hip Fracture in Elderly Women. J. Clin. Investig. 1993, 91, 1769-1774. [CrossRef]

150. Rønn, S.H.; Harsløf, T.; Pedersen, S.B.; Langdahl, B.L. Vitamin K2 (Menaquinone-7) Prevents Age-Related Deterioration of Trabecular Bone Microarchitecture at the Tibia in Postmenopausal Women. Eur. J. Endocrinol. 2016, 175, 541-549. [CrossRef]

151. Murshed, M. Unique Coexpression in Osteoblasts of Broadly Expressed Genes Accounts for the Spatial Restriction of ECM Mineralization to Bone. Genes Devel. 2005, 19, 1093-1104. [CrossRef] [PubMed]

152. Cockayne, S.; Adamson, J.; Lanham-New, S.; Shearer, M.J.; Gilbody, S.; Torgerson, D.J. Vitamin K and the Prevention of Fractures: Systematic Review and Meta-Analysis of Randomized Controlled Trials. Arch. Intern. Med. 2006, 166, 1256-1261. [CrossRef]

153. Schurgers, L.J.; Spronk, H.M.H.; Soute, B.A.M.; Schiffers, P.M.; DeMey, J.G.R.; Vermeer, C. Regression of Warfarin-Induced Medial Elastocalcinosis by High Intake of Vitamin K in Rats. Blood 2007, 109, 2823-2831. [CrossRef]

154. McCabe, K.M.; Booth, S.L.; Fu, X.; Shobeiri, N.; Pang, J.J.; Adams, M.A.; Holden, R.M. Dietary Vitamin K and Therapeutic Warfarin Alter the Susceptibility to Vascular Calcification in Experimental Chronic Kidney Disease. Kidney Intern. 2013, 83, 835-844. [CrossRef]

155. Thijssen, H.H.W.; Vervoort, L.M.T.; Schurgers, L.J.; Shearer, M.J. Menadione Is a Metabolite of Oral Vitamin K. Br. J. Nutr. 2006, 95, 260-266. [CrossRef]

156. Haugsgjerd, T.R.; Egeland, G.M.; Nygård, O.K.; Vinknes, K.J.; Sulo, G.; Lysne, V.; Igland, J.; Tell, G.S. Association of Dietary Vitamin K and Risk of Coronary Heart Disease in Middle-Age Adults: The Hordaland Health Study Cohort. BMJ Open 2020, 10, e035953. [CrossRef]

157. Knapen, M.H.J.; Braam, L.A.J.L.M.; Drummen, N.E.; Bekers, O.; Hoeks, A.P.G.; Vermeer, C. Menaquinone-7 Supplementation Improves Arterial Stiffness in Healthy Postmenopausal Women: A Double-Blind Randomised Clinical Trial. Thromb. Haemost. 2015, 113, 1135-1144. [CrossRef]

158. Braam, L.A.J.L.M.; Knapen, M.H.J.; Geusens, P.; Brouns, F.; Hamulyk, K.; Gerichhausen, M.J.W.; Vermeer, C. Vitamin K1 Supplementation Retards Bone Loss in Postmenopausal Women between 50 and 60 Years of Age. Calc. Tissue Internat. 2003, 73, 21-26. [CrossRef] [PubMed]

159. Schurgers, L.J.; Knapen, M.H.J.; Vermeer, C. Vitamin K2 Improves Bone Strength in Postmenopausal Women. Int. Congr. Ser. 2007, 1297, 179-187. [CrossRef] 
160. Krüger, T.; Oelenberg, S.; Kaesler, N.; Schurgers, L.J.; van de Sandt, A.M.; Boor, P.; Schlieper, G.; Brandenburg, V.M.; Fekete, B.C.; Veulemans, V.; et al. Warfarin Induces Cardiovascular Damage in Mice. Arterioscler. Thromb. Vasc. Biol. 2013, 33, $2618-2624$. [CrossRef] [PubMed]

161. Westenfeld, R.; Krueger, T.; Schlieper, G.; Cranenburg, E.C.M.; Magdeleyns, E.J.; Heidenreich, S.; Holzmann, S.; Vermeer, C.; Jahnen-Dechent, W.; Ketteler, M.; et al. Effect of Vitamin K2 Supplementation on Functional Vitamin K Deficiency in Hemodialysis Patients: A Randomized Trial. Am. J. Kidney Dis. 2012, 59, 186-195. [CrossRef] [PubMed]

162. Huang, Z.-B.; Wan, S.-L.; Lu, Y.-J.; Ning, L.; Liu, C.; Fan, S.-W. Does Vitamin K2 Play a Role in the Prevention and Treatment of Osteoporosis for Postmenopausal Women: A Meta-Analysis of Randomized Controlled Trials. Osteoporos. Int. 2015, 26, 1175-1186. [CrossRef]

163. Alexopoulos, N.; Raggi, P. Calcification in Atherosclerosis. Nat. Rev. Cardiol. 2009, 6, 681-688. [CrossRef] [PubMed]

164. Alexopoulos, N.; Raggi, P. Coronary Artery Calcium Is a Better Risk Marker than HsCRP. Nat. Rev. Cardiol. 2011, 8, 616-618. [CrossRef]

165. Rennenberg, R.; Kessels, A.G.H.; Schurgers, L.J.; Van Engelshoven, J.M.A.; de Leeuw, P.; Kroon, A.A. Vascular Calcifications as a Marker of Increased Cardiovascular Risk: A Meta-Analysis. Vasc. Health Risk Manag. 2009, 5, 185-197. [CrossRef]

166. van Summeren, M.J.H.; Braam, L.A.J.L.M.; Lilien, M.R.; Schurgers, L.J.; Kuis, W.; Vermeer, C. The Effect of Menaquinone-7 (Vitamin K2) Supplementation on Osteocalcin Carboxylation in Healthy Prepubertal Children. Br. J. Nutr. 2009, 102, 1171-1178. [CrossRef] [PubMed]

167. Knapen, M.H.J.; Jardon, K.M.; Vermeer, C. Vitamin K-Induced Effects on Body Fat and Weight: Results from a 3-Year Vitamin K2 Intervention Study. Eur. J. Clin. Nutr. 2018, 72, 136-141. [CrossRef]

168. Lees, J.S.; Chapman, F.A.; Witham, M.D.; Jardine, A.G.; Mark, P.B. Vitamin K Status, Supplementation and Vascular Disease: A Systematic Review and Meta-Analysis. Heart 2018, 105, 938-945. [CrossRef]

169. Zhang, S.; Guo, L.; Bu, C. Vitamin K Status and Cardiovascular Events or Mortality: A Meta-Analysis. Eur. J. Prev. Cardiol. 2019, 26, 549-553. [CrossRef]

170. de Baaji, J.H.F.; Hoenderp, J.G.J.; Bindels, R.J.M. Magnesium in Man: Implications for Health and Disease. Physiol. Rev. 2015, 95, 1-46. [CrossRef] [PubMed]

171. Laires, M.J. Role of Cellular Magnesium in Health and Human Disease. Front. Biosci. 2004, 9, 262. [CrossRef] [PubMed]

172. Ford, E.S.; Mokdad, A.H. Dietary Magnesium Intake in a National Sample of U.S. Adults. J. Nutr. 2003, 133, 2879-2882. [CrossRef]

173. Cowan, A.; Jun, S.; Bhadra, A.; Dodd, K.; Dwyer, J.; Eicher-Miller, H.; Gahche, J.; Potischman, N.; Tooze, J.; Bailey, R. Dietary Supplements Contributed Substantially to Total Intakes and Nutritional Adequacy of Several Micronutrients among U.S. Adults, NHANES 2011-2014 (OR14-07-19). Curr. Dev. Nutr. 2019, 3. [CrossRef]

174. U.S. Department of Agriculture; U.S. Department of Health and Human Services. Dietary Guidelines for Americans, 2010; U.S. Government Printing Office: Washington, DC, USA, 2010.

175. Papanikolaou, Y.; Brooks, J.; Reider, C.; Fulgoni, V.L. Comparison of Inadequate Nutrient Intakes in Non-Hispanic Blacks vs. Non-Hispanic Whites: An Analysis of NHANES 2007-2010 in U.S. Children and Adults. J. Health Care Poor Underserved 2015, 26, 726-736. [CrossRef] [PubMed]

176. Jun, S.; Cowan, A.E.; Bhadra, A.; Dodd, K.W.; Dwyer, J.T.; Eicher-Miller, H.A.; Gahche, J.J.; Guenther, P.M.; Potischman, N.; Tooze, J.A.; et al. Older Adults with Obesity Have Higher Risks of Some Micronutrient Inadequacies and Lower Overall Dietary Quality Compared to Peers with a Healthy Weight, National Health and Nutrition Examination Surveys (NHANES), $2011-2014$. Public Health Nutr. 2020, 23, 2268-2279. [CrossRef]

177. Liu, J.; Zhu, X.; Fulda, K.G.; Chen, S.; Tao, M.-H. Comparison of Dietary Micronutrient Intakes by Body Weight Status among Mexican-American and Non-Hispanic Black Women Aged 19-39 Years: An Analysis of NHANES 2003-2014. Nutrients 2019, 11, 2846. [CrossRef]

178. Schuchardt, J.P.; Hahn, A. Intestinal Absorption and Factors Influencing Bioavailability of Magnesium- An Update. Curr. Nutr. Food Sci. 2017, 13. [CrossRef] [PubMed]

179. Nielsen, F.H. The Problematic Use of Dietary Reference Intakes to Assess Magnesium Status and Clinical Importance. Biol. Trace Elem. Res. 2019, 188, 52-59. [CrossRef]

180. Cheung, M.M.; DeLuccia, R.; Ramadoss, R.K.; Aljahdali, A.; Volpe, S.L.; Shewokis, P.A.; Sukumar, D. Low Dietary Magnesium Intake Alters Vitamin D-Parathyroid Hormone Relationship in Adults Who Are Overweight or Obese. Nutr. Res. 2019, 69, 82-93. [CrossRef]

181. Reddy, P.; Edwards, L.R. Magnesium Supplementation in Vitamin D Deficiency. Am. J. Therapeut. 2019, 26, e124-e132. [CrossRef]

182. Hunt, C.D.; Johnson, L.K. Magnesium Requirements: New Estimations for Men and Women by Cross-Sectional Statistical Analyses of Metabolic Magnesium Balance Data. Am. J. Clin. Nutr. 2006, 84, 843-852. [CrossRef]

183. Rosanoff, A. Perspective: US Adult Magnesium Requirements Need Updating: Impacts of Rising Body Weights and Data-Derived Variance. Adv. Nutr. 2021, 12, 298-304. [CrossRef]

184. Williamson, M.A.; Snyder, L.M.; Wallach, J.B. Wallach's Interpretation of Diagnostic Tests, 9th ed.; Wolters Kluwer; Lippincott Williams \& Wilkins: Philadelphia, PA, USA, 2011; Volume XVI.

185. Lowenstein, F.W.; Stanton, M.F. Serum Magnesium Levels in the United States, 1971-1974. J. Am. Coll. Nutr. 1986, 5, 399-414. [CrossRef] [PubMed] 
186. Costello, R.B.; Elin, R.J.; Rosanoff, A.; Wallace, T.C.; Guerrero-Romero, F.; Hruby, A.; Lutsey, P.L.; Nielsen, F.H.; Rodriguez-Moran, M.; Song, Y.; et al. Perspective: The Case for an Evidence-Based Reference Interval for Serum Magnesium: The Time Has Come. Adv. Nutr. 2016, 7, 977-993. [CrossRef] [PubMed]

187. Al Alwi, A.M.; Majoni, S.W.; Falhammar, H. Magnesium and Human Health: Perspectives and Research Directions. Int. J. Endocrinol. 2018, 2018, 1-17. [CrossRef] [PubMed]

188. Costello, R.B.; Nielsen, F. Interpreting Magnesium Status to Enhance Clinical Care-Key Indicators. Curr. Opin. Clin. Nutr. Metab. Care 2018, 504-511. [CrossRef]

189. Institute of Medicine. Evaluation of Biomarkers and Surrogate Endpoints in Chronic Disease; The National Academies Press: Washington, DC, USA, 2010; ISBN 978-0-309-15129-0.

190. Zhang, X.; Xia, J.; Del Gobbo, L.C.; Hruby, A.; Dai, Q.; Song, Y. Serum Magnesium Concentrations and All-Cause, Cardiovascular, and Cancer Mortality among U.S. Adults: Results from the NHANES I Epidemiologic Follow-up Study. Clin. Nutr. 2018, 37, 1541-1549. [CrossRef]

191. Bertinato, J.; Wang, K.; Hayward, S. Serum Magnesium Concentrations in the Canadian Population and Associations with Diabetes, Glycemic Regulation, and Insulin Resistance. Nutrients 2017, 9, 296. [CrossRef] [PubMed]

192. Basiotis, P.P.; Welsh, S.O.; Cronin, F.J.; Kelsay, J.L.; Mertz, W. Number of Days of Food Intake Records Required to Estimate Individual and Group Nutrient Intakes with Defined Confidence. J. Nutr. 1987, 117, 1638-1641. [CrossRef]

193. Rollo, M.E.; Williams, R.L.; Burrows, T.; Kirkpatrick, S.I.; Bucher, T.; Collins, C.E. What Are They Really Eating? A Review on New Approaches to Dietary Intake Assessment and Validation. Curr. Nutr. Rep. 2016, 5, 307-314. [CrossRef]

194. Bush, C.L.; Blumberg, J.B.; El-Sohemy, A.; Minich, D.M.; Ordovás, J.M.; Reed, D.G.; Behm, V.A.Y. Toward the Definition of Personalized Nutrition: A Proposal by the American Nutrition Association. J. Am. Coll. Nutr. 2020, 39, 5-15. [CrossRef]

195. Srinivasan, B.; Lee, S.; Erickson, D.; Mehta, S. Precision Nutrition—Review of Methods for Point-of-Care Assessment of Nutritional Status. Curr. Opin. Biotechnol. 2017, 44, 103-108. [CrossRef] 